\title{
Loess-Palaeosol-Sequences from the loess area of Saxony [Germany]
}

\author{
Sascha Meszner, Markus Fuchs, Dominik Faust
}

Abstract:

Based on new descriptions of loess-palaeosol profiles, we present a new composite profile for the loess region of Saxony, Germany. In addition to former studies of LIEBEROTH $\mho$ HAASE new stratigraphic marker horizons and palaeosols were added. Concerning the so far poorly differentiated Weichselian pleniglacial we identified three palaeosols. A palaeoclimatic interpretation for the last glacial (Weichselian) is presented and discussed.

[Löss-Paläobodenprofile aus dem Sächsischen Lösshügelland [Deutschland]]

\begin{abstract}
Kurzfassung:
Auf der Grundlage von neu aufgenommenen Lössprofilen im sächsischen Lösshügelland wird ein Standardprofil für die Region vorgestellt. Den früheren Arbeiten von LiEвеRотн \& HAASE konnten neue stratigraphische Markerhorizonte und Paläoböden hinzugefügt werden. Besonders im bisher kaum differenzierten Hochweichsel konnten 3 Paläobodenhorizonte detektiert werden. Aus den neuen Befunden zu den Löss-Paläobodensequenzen Sachsens wird eine Klimarekonstruktion abgeleitet und zur Diskussion gestellt
\end{abstract}

Keywords: $\quad$ loess, palaeosol, palaeoclimate, Weichselian, Saxony, Germany

Addresses of authors: S. Meszner ${ }^{*}$ D. Faust, Institute of Geography, Dresden University of Technology, 01062 Dresden, Germany. E-Mail: sascha.meszner@tu-dresden.de; M. Fuchs, Geographical Institute, University of Bayreuth, 95440 Bayreuth, Germany. *corresponding author

\section{Introduction}

The Saxonian Loess Region is situated in the center of Saxony, East Germany (Fig. 1) and represents the transition zone between the North European Plain and the Central Upland (Erzgebirge). In this area of gently rolling hills, a loess cover of up to $20 \mathrm{~m}$ was accumulated during the last glacial cycle (Weichselian), intercalated by a number of palaeosols. These loess-palaeosol sequences represent an excellent sediment archive for reconstructing environmental and climate change of the last glacial cycle.

The first study of loess sediments in Saxony was carried out by PiETzSCH (1922), dividing the sedimentary record into two main parts; one lower part with reworked sandy loess sediments and an upper one composed of more or less pure loess. In the following years, studies were focused on loess distribution and on the general composition of loess and loess-like sediments (GrahmANn, 1925). In a first approach GALLWITZ (1937) described a section close to the Elbe river, where he was able to distinguish several loess layers with intercalated levels of ice wedges and reworked loess. GRAHMANN (1932) published the first map of loess distribution in Europe.

Since 1950 the loess in Saxony was subject of intense palaeopedologic and stratigraphic investigation. Based on several sections LIEBEROTH built up a stratigraphy, which is accepted until now (LiEBEROTH 1959, 1962a, 1963, 1964a, 1964b). Later on HAASE $(1963,1968)$ and Neumeister (1966) worked on geomorphic features of the northern loess boundary (Lössrandstufe). At this time, the loess research of Eastern Germany was summarized by GELLERT (1965) and RicH-
TER et al. (1970). Since then, only a few articles were published (Altermann et al. 1978; BIERING \& FrüHAuf 1999; Meng 2003; Zoeller et al. 2004; КосH ひ Neumeister 2005). A systematic approach with further results is still lacking.

In the present study the existing results are summarized in respect to the Saxonian loess stratigraphy and improved by new findings to broaden our knowledge of loess-palaeosol sequences in Saxony. As most sections mentioned before are inaccessible today, new sections had to bee opened for this study. Due to the fact that loess-palaeosol sequences of Saxony represent an important link between the Western European loess records formed under moister conditions and the Bohemian loess records formed under more continental conditions, the Saxonian Loess Region provides valuable information about the palaeoclimate change in this transitional zone.

\subsection{Geographical setting}

The Saxonian Loess Region is situated in East Germany, west of the city of Dresden and characterized by gently rolling hills, covered by up to $20 \mathrm{~m}$ thick loess accumulations (Fig 1). The landscape is dissected by small rivers incised into the loess cover down to the bedrock (Granite of Meissen). The loess was deposited in the foreland of the Erzgebirge, forming a plateau-like topography, representing the so-called "Saxonian Loess Plateau". Surrounded by deep incised valleys of the Elbe and the Mulde River the landscape is and was endangered by soil erosion processes even in former times. 


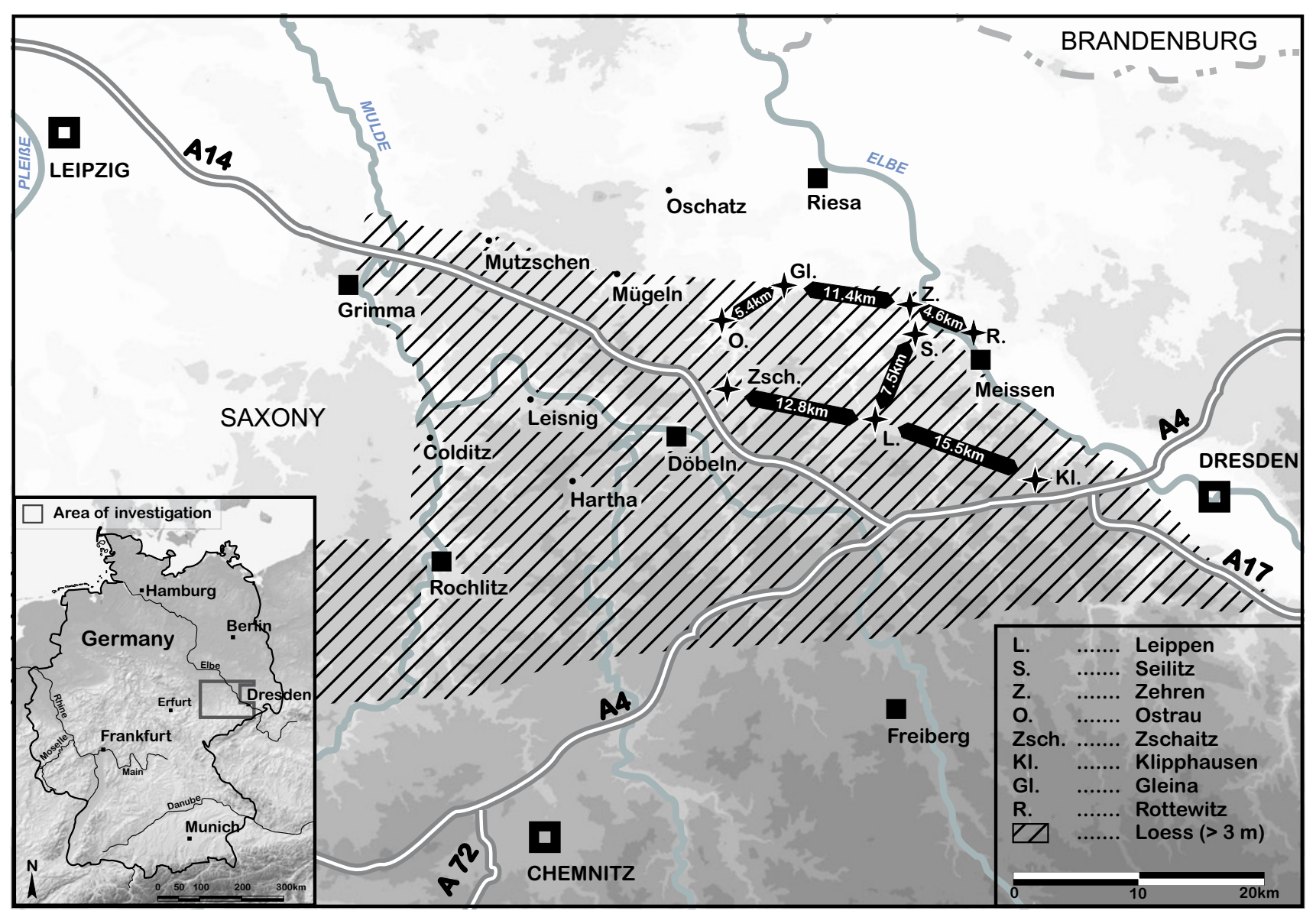

Fig. 1: Map showing study area and distribution of loess (>3 $m$ thickness).

Abb. 1: Die Karte zeigt die untersuchten Profile und Lössverbreitung (mächtiger als $3 \mathrm{~m}$ ) im Arbeitsgebiet.

In the Early to Middle Pleistocene the study area was covered by the ice shield of the "Elster Glaciation". From the First Saalian Glaciation glacial deposits are described by EISSMANN (1994). These deposits were reworked and enriched by loess deposits of the Late Saalian Glaciation (Warthe), which evidence that the Late Saalian ice advance stopped some kilometres further north. The last period of loess accumulation took place during the Weichselian Glaciation.

The fertile soils, formed during late Pleistocene and Holocene, were cultivated by early farmers around $7500 \mathrm{BP}$ (cf. OEXLE 2000). Today the landscape is characterized by varying soil patterns showing a mosaic of truncated luvisols of different stages owing to extended agricultural activity. The valley bottoms are filled by colluvial material up to $4 \mathrm{~m}$ thick. Some strongly eroded hill slopes show that the underlying calcareous loess is already at the surface and is mixed into the soil by modern ploughing. In positions of little erosion we assume a deepness of decalcified loess due to soil formation of about $1.8 \mathrm{~m}$. We conclude that at some places more than $2 \mathrm{~m}$ of soil was eroded.

Today the mean annual temperature is about $8.8^{\circ} \mathrm{C}$, as determined in a nearby climate station (Döbeln). The mean annual precipitation is about $600 \mathrm{~mm}$ with it's maximum in summer.

\section{Methods}

\section{Field Work}

In order to select the locations for detailed field work and profile description, the study area was investigated using aerial and satellite images. After deciding to open seven new sections, field work included cleaning, drawings, and sampling of each profile. The samples were taken in respect to the layering of the section. Some sections were sampled equidistant with a $2 \mathrm{~cm}$ resolution. Standard sedimentological and pedological analyses like granulometry, $\mathrm{pH}$ value, carbonate content, soil organic matter, and content of several iron compounds were conducted in the laboratory of the Institute of Geography (Dresden University of Technology). During field work we already established a preliminary litho- and pedostratigraphy with focus on the identification of loess-palaeosol complexes. Magnetic susceptibility was measured in SI units in the field with a portable Bartington MS2 susceptibility meter. For this purpose we chose an interval of less than $5 \mathrm{~cm}$. Commonly, three measurements were averaged (cf. DEARING, 1999).

\section{Sedimentology}

At the Institute of Geography (Dresden), soil textures were analysed. Bulk sample (10 g) was mixed with $25 \mathrm{ml}$ dispersing solution (sodium hexametaphosphate: $\left(\mathrm{NaPO}_{3}\right)_{6}-39 \mathrm{~g} / \mathrm{l}$ $\mathrm{H}_{2} \mathrm{O}$ ) and $200 \mathrm{ml} \mathrm{H}_{2} \mathrm{O}$. After rotating the suspension for at 
least $2 \mathrm{~h}$ it was stored for $12 \mathrm{~h}$ for complete dispersion. The grain-size measurements of the sand fraction were carried out by means of the wet sieve technique $(2.0-0.63 \mathrm{~mm}$ : coarse sand; 0.63-0.2 mm: medium sand; $0.2-0.125 \mathrm{~mm}$ : fine sand; 0.125-0.063 mm: finest sand). Coarse silt $(0.063-0.02 \mathrm{~mm})$, medium silt $(0.02-0.0063 \mathrm{~mm})$, fine silt $(0.0063-0.002 \mathrm{~mm})$ and clay $(<0.002 \mathrm{~mm})$ were measured by pipette analyses (Schlichting et al., 1995).

The carbonate content was determined by $\mathrm{CO}_{2}$ gas volume. Soil samples were added with hydrochloric acid in a closed system, and the resulting $\mathrm{CO}_{2}$ gas volume was measured by a Scheibler apparatus (cf. Schlichting et al., 1995). The soil organic matter (SOM) was determined by oxidation with $\mathrm{K}_{2} \mathrm{Cr}_{2} \mathrm{O}_{7}$ in a concentrated $\mathrm{H}_{2} \mathrm{SO}_{4}$ medium and measurement of absorbance at $590 \mathrm{~nm}$ (cf. Schlichting et al., 1995). The $\mathrm{pH}$ value was determined in a 1:2.5 soil/solution ratio in $25 \mathrm{ml}$ $0.01 \mathrm{M} \mathrm{CaCl}_{2}$ (cf. Schlichting et al.). After $30 \mathrm{~min}$ stirring the suspension, the $\mathrm{pH}$ value was measured.

For extracting the pedogenic iron compound $\left(\mathrm{Fe}_{\mathrm{d}}\right)$, soil samples were deferrated by the bicarbonate-buffered dithionitecitrate procedure (cf. Schlichting et al., 1995). To determine the total iron content $\left(\mathrm{Fe}_{\mathrm{t}}\right), 100 \mathrm{mg}$ soil material was digested with $2 \mathrm{ml}$ concentrated nitric acid $\left(\mathrm{HNO}_{3}\right)$ and $2 \mathrm{ml}$ concentrated hydrofluoric acid (HF) using steam autoclaves. The amounts of pedogenic $\left(\mathrm{Fe}_{\mathrm{d}}\right)$ and total $\left(\mathrm{Fe}_{\mathrm{t}}\right)$ iron were measured using an atomic absorption spectrometer.

\section{Mollusk analyses}

The mollusk analyses were carried out by HAMANN (2010 unpub.). Samples of about 10 to $15 \mathrm{~kg}$ were taken, sieved (200 or
$400 \mu \mathrm{m}$ mesh size) and washed to extract the mollusk shells, which were counted and identified. The species were classified according to LožEK (1964).

\section{IRSL Dating}

Samples for IRSL dating were taken using steel cylinders, hammered into the cleaned loess section to avoid any contamination of the samples with light-exposed material. Sample preparation was performed under subdued red light (640 $\pm 20 \mathrm{~nm})$, using the polymineral fine-grain fraction $(4-11 \mu \mathrm{m})$ for luminescence measurements.

The equivalent dose (De) was determined applying a multiple aliquot additive dose protocol. To construct a saturating exponential growth curve for De determination, 10 natural aliquots and six groups of artificially irradiated aliquots (five each) were used. Artificial irradiation was carried out with a ${ }^{90} \mathrm{~S} /{ }^{90} \mathrm{Y}$ b-source $(9.9 \mathrm{~Gy} / \mathrm{min})$. During IR stimulation (880 $\mathrm{nm}$ $\pm 80 \mathrm{~nm}$ ), the shine-down curves were measured for $60 \mathrm{~s}$ at room temperature after a preheat at $220^{\circ} \mathrm{C}$ for $300 \mathrm{~s}$ and using a detection filter combination of BG39, 2 x BG3 and GG400 (390-450 nm). Before IRSL measurements, the samples were stored (room temperature) for a minimum of one month after artificial irradiation. Finally, the Dewas calculated from the 0-40 s signal integral after subtracting the 'late light' signal of the 55-60 s integral (AITKEN \& XIE 1992). In addition, an extra set of aliquots was used to test for anomalous fading and to determine the $\alpha$-efficiency (a-value) of the measured material. No anomalous fading was detected. Dose rates were obtained using low-level $\gamma$-spectrometry and conversion factors given by ADAMIEC \& AitKen (1998).

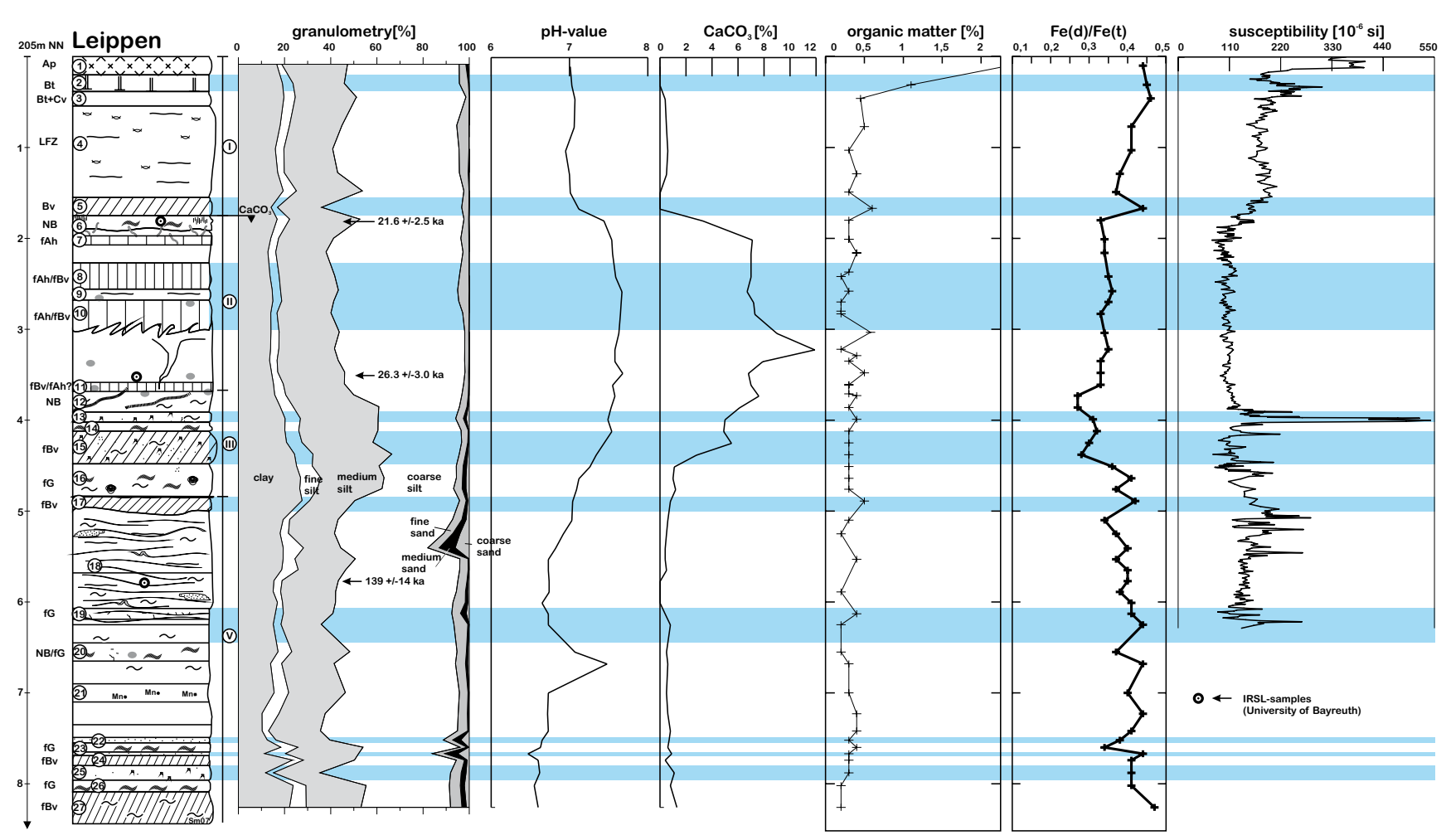

Fig. 2: Profile Leippen with geochemical results.

Abb. 2: Profil Leippen mit den dazugehörigen geochemichen Analyseergebnissen. 


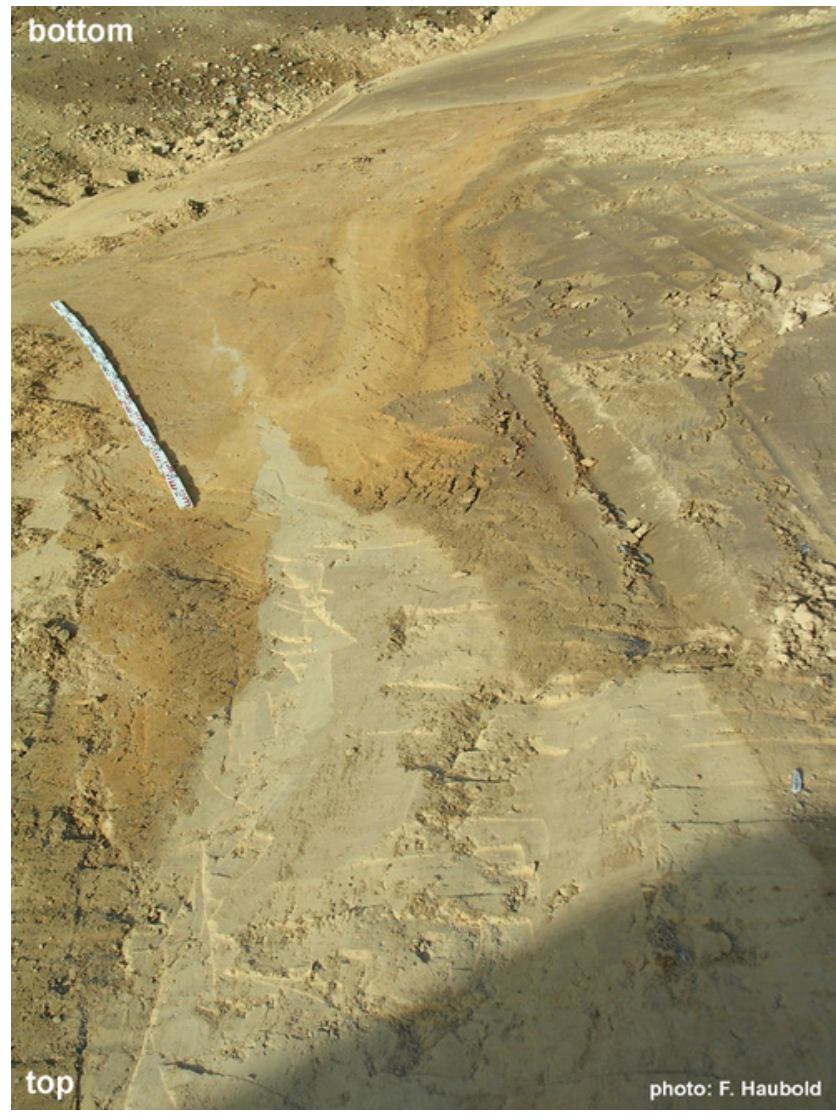

Fig. 3: Big ice wedges at the section Leippen (photo is upside down). Abb. 3: Mächtige Eiskeilpseudomorphose im Profil Leippen (Foto steht auf dem Kopf).

\section{Results}

\subsection{Section Leippen [Tab. 1; Fig. 2]}

Due to roadcuts close to the village of Leippen (GK R 459345 $H$ 566726) this section was open in summer 2005. A detailed description is given in Tab. 1. In general the section could be subdivided into four units, beginning at the top with a darkish decalcified part in which the Holocene soil is developed. The decalcification boundary at about $2 \mathrm{~m}$ is the lowermost limit of this unit. The underlying calcareous loess is characterized by a light yellowish colour and a typical porous fabric. This unit is composed of pure loess and resorted loess derivates wherein some darkish or reddish parts could be detected and are seen as interstadial soil features. During the deposition of this unit huge ice wedges were formed reaching even into the subjacent unit (Fig. 3).

The unit beneath is dominated by solifluction processes which generated different smaller layers. The whole unit shows markedly stronger colouring. The base is composed of material which seems to have undergone strong soil redeposition. The lowest unit is subdivided into two parts. The upper part shows a strong lamination with platy fabric including sandy bands indicating abluation processes; the lower part is less laminated and has a weaker structure. We assume that the lowest unit is already composed of Saalian deposits. A sample from the lower part of layer 18 shows an IRSL-age of $139+/-14 \mathrm{ka}$. Combining this IRSL-age with the increase of clay and sand in layer 16 and 17 and the increase of Fe-ratio we suspect a significant hiatus in this section. This hiatus is result of an erosion phase which hits the Eemian soil and the Early Weichelian deposits.

The geochemical analyses (Fig. 2) support the division into these units.

\subsection{Section Seilitz [Tab. 2; Fig. 4]}

The section is located close to the village of Seilitz (GK $\mathrm{R} 5388260, \mathrm{H} 5673750$ ) in a kaolin pit $1.5 \mathrm{~km}$ southwest of the recent course of the river Elbe. A detailed description is given in Tab. 2. The loess record covers a thick kaolin horizon derived from strong alteration processes of the monzodiorite. In between, a small sandy gravel layer is developed which is interpreted as remnants of moraine material of Saalian age. This stratigraphical situation makes a Weichselian loess deposition most likely. Following the different features within the whole loess section we propose to subdivide the Weichselian loess deposits into three units. According to the Leippen section the uppermost unit, a decalcified loess, correlates to the late Weichselian with the recent soil at the top. The following unit is about $5 \mathrm{~m}$ thick and contains several interstadial soils with the upper soil showing strong hydromorphic features (Fig. 4; layer 5 and 6). A dark grey horizon (layer 10) is seen as the strongest palaeosol-(sediment) in this section. The lower brownish palaeosol forms layer 12 . The lower unit III is characterized by layers indicating strong solifluction, which are also recognizable at the section of Leippen (Fig. 5). Geochemical analyses such as the increased content of sand and clay (Fig. 4) show congruent results. For example the dark grey horizon (layer 10) shows enrichment of carbonate and of SOM. The $\mathrm{pH}$-value marks the carbonate free parts of the Holocene soil development and fits well with the analyses of the carbonate content.

\subsection{Section Zehren [Tab. 3; Fig. 6]}

The Zehren section (GK R $4597625 \mathrm{H}$ 5675325) is situated about $1.5 \mathrm{~km}$ to the north of Seilitz section. Tab. 3 contains a summarized description. At the top of the section a weak humic calcareous horizon is developed which indicates strong erosion processes in former times. We assume that at least $2 \mathrm{~m}$ of soil and loess material is lacking. Therefore the described unit from the top of section Seilitz and Leippen is not preserved in section Zehren. At about $3 \mathrm{~m}$ depth we detected a notable humic horizon with remarkable dark grayish colouring (layer 9) which has not been described in former studies. The main features of this horizon are the strong colour and the distinct lower and upper boundary. The base of this unit (layer 20) marks the boundary between loess and loess sediment (Fig. 6). From a depth of $7 \mathrm{~m}$ (layer 21) the section is composed of strongly reworked loess derivates up to a depth of $11 \mathrm{~m}$. Considering the fact that at the top of this section $2 \mathrm{~m}$ of loess are missing we believe that this sections represents the thickest loess accumulation of the study area.

\subsection{Section Ostrau [Tab. 4; Fig. 7]}

This section is situated close to the town of Ostrau (GK $\mathrm{R} 4582462 \mathrm{H} \mathrm{5675008)}$ in a limestone pit of the Ostrauer 
Kalkwerke $\mathrm{GmbH}$ and contains the most complete Weichselian loess sequence including the last interglacial palaeosol (Eemian). Tab. 4 shows a detailed description of section Ostrau. According to the sections of Leippen and Seilitz we are able to subdivide the sequence from section Ostrau into three upper units as well. As the section reaches into the last interglacial palaeosol, we added a fourth unit at the bottom of this section. From the top we observe the typical sequence starting with decalcified loess which includes the first three layers (Fig. 7). Unit II starts with layer 4 and ends at about $5 \mathrm{~m}$ depth with layer 8 . In layer 5 , a slightly reworked but strong soil is developed which we correlate with the strong soil at section Zehren (Fig. 6, layer 9). This soil formed after a stronger phase of reorganization of the surface as evidenced by deep gullies which are filled up (layer 5). A detailed draft (Fig. 8) of the upper part of the section shows the incision into layer 6 .

The lowermost unit begins with layer 9 in which big ice wedges could be observed. Stratigraphically they belong to layer 8 (unit II). The lowermost unit III is composed of several derived loess layers and soil sediments indicating several environmental changes during this time. The grey solifluction layer (11) and the reddish loam (layer 12) mark the boundary between unit III and unit IV.

\section{Tab. 1: Description of section Leippen.}

\section{Tab. 1: Profilbeschreibung Leippen.}

\begin{tabular}{|c|c|c|}
\hline Layer & Label & Description \\
\hline 1 & Ap & humic dark horizon with a clear lower boundary \\
\hline 2 & Bt & $\begin{array}{l}\text { reddish brown clay enriched compact loam, weak pinprick structure and sporadically hydromorphic features [rust } \\
\text { stains] }\end{array}$ \\
\hline 3 & $\mathrm{Bt}+\mathrm{Cv}$ & less clay than layer 2 , oval bleached patches [diameter $5 \mathrm{~mm}$ ], pinpricks \\
\hline 4 & LFZ & lamellar line-like structure between brownish clay-enriched [10Y5/6] and yellowish coarse silt [10Y6/4] \\
\hline 5 & Bv & $\begin{array}{l}\text { homogeneous light brownish grey, non calcareous silt, typical loosely packed loess structure with sporadic fine } \\
\text { Manganese concretions, old backfilled earthworm burrows }\end{array}$ \\
\hline 6 & NB & $\begin{array}{l}\text { bedded light greyish calcareous loess with iron hydroxide lines, undulated lower boundary, old backfilled earthworm } \\
\text { burrows [current term in work: bio-traces] }\end{array}$ \\
\hline 7 & fAh & pale slightly dark loess \\
\hline 8 & $\mathrm{fAh} / \mathrm{fBv}$ & brown greyish homogeneous loess with pseudomycelia and sporadic big Mn-stains, \\
\hline 9 & & slight lamellar structure, light brown, big Mn-stains \\
\hline \multirow[t]{2}{*}{10} & $\mathrm{fAh} / \mathrm{fBv}$ & brown greyish homogeneous loess with pseudomycelia, undulating lower limit \\
\hline & & laminated loess with big Manganese stains \\
\hline 11 & $\mathrm{fAh} / \mathrm{fBv} ?$ & pale dark homogeneous loamy loess \\
\hline 12 & NB & grey brownish loam with a typical iron-oxide grid \\
\hline 13 & & loamy, brown greyish loess derivate, numerous Mn-concretions [solifluction layer] \\
\hline 14 & & loam, grey, brown with some little stones \\
\hline 15 & $\mathrm{fBv}$ & [soil sediment] stony [pebbles] layer, dark grey brown, numerous Mn-concretions, dense layering \\
\hline 16 & fG & bleached grey layer with rosty tubes, hydromorphic features \\
\hline 17 & $\mathrm{fBv}$ & reddish sandy material with cryoturbation features, parts with microstructure \\
\hline 18 & & clearly laminated material with sandy, loamy and silty layers [10YR5/6, 5/4, 6/8,5/6], platy microstructure \\
\hline 19 & fG & grey-[light purple]-bleached loam \\
\hline 20 & $\mathrm{NB} / \mathrm{fG}$ & grey-[light purple]-bleached loam, iron-oxides \\
\hline 21 & & Manganese enriched loam \\
\hline 22 & & thin layer of sand \\
\hline 23 & fG & grey-[light purple]-bleached loam \\
\hline 24 & $\mathrm{fBv}$ & [soil sediment] clay enriched, reddish brown soil sediment \\
\hline 25 & & yellowish loess \\
\hline 26 & fG & grey-[light purple]-bleached loam \\
\hline 27 & $\mathrm{fBv}$ & [soil sediment] stained silt, grey brown yellowish \\
\hline
\end{tabular}




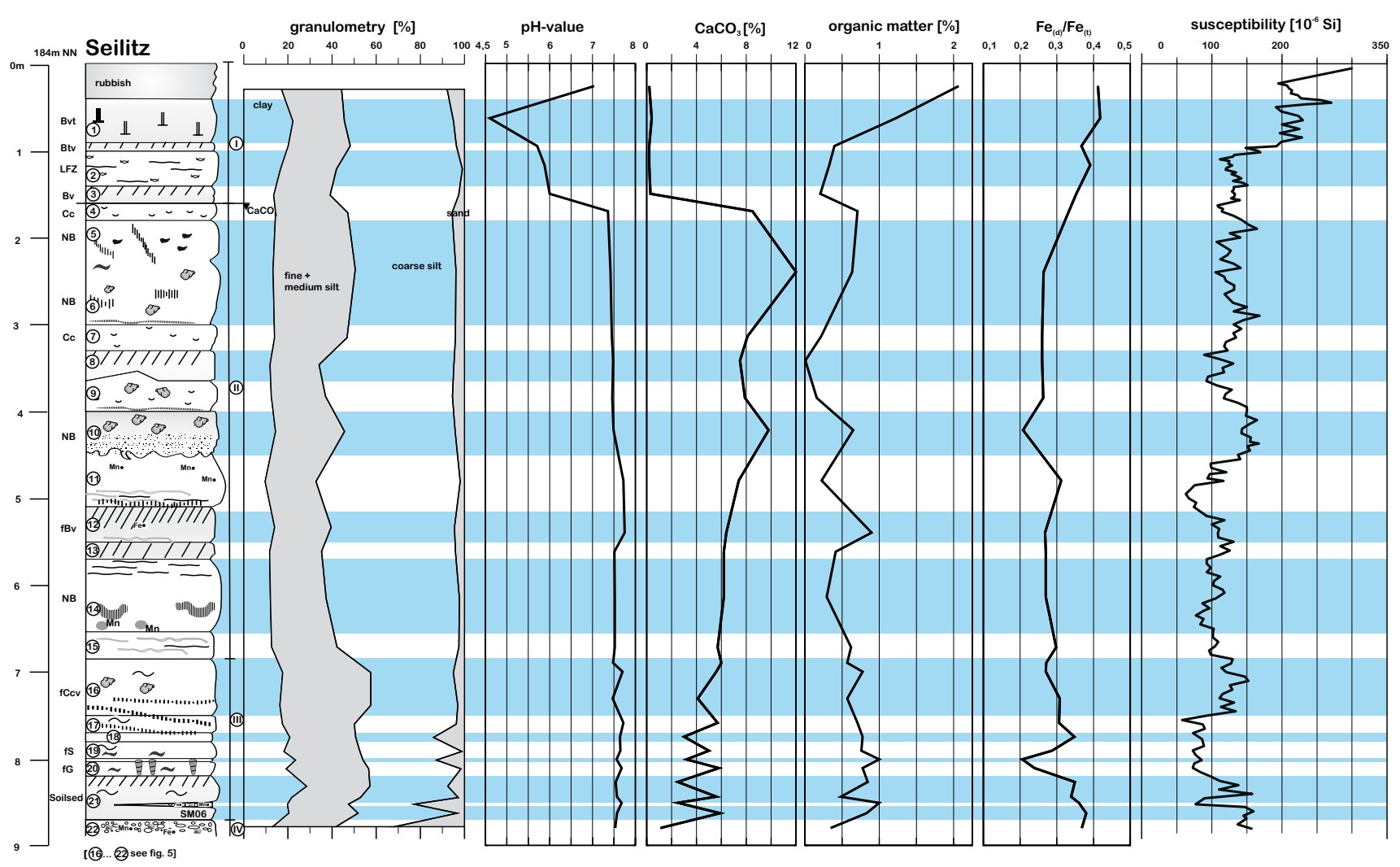

Fig. 4: Profile Seilitz with geochemical results.

Abb. 4: Profil Seilitz mit den dazugehörigen geochemichen Analyseergebnissen.

\section{Seilitz}



Fig. 5: Lower part of the section Seilitz (Nr.9: filled ice wedge).

Abb. 5: Der untere Wandabschnitt im Profil Seilitz (Nr. 9: Eiskeilpseudomorphose). 
Tab. 2: Description of section Seilitz.

Tab. 2: Profilbeschreibung Seilitz. NB = Naßboden

\begin{tabular}{|c|c|c|}
\hline Layer & Label & Description \\
\hline 1 & Bvt & brown illuvial horizon with weak hydromorphic features, in the lower part prismatic structure \\
\hline 2 & LFZ & $\begin{array}{l}\text { a very typical expression of lenticular horizon!; lamellar line-like structure between brownish clay-enriched and yellowish } \\
\text { coarse silt, pores increasing with depth }\end{array}$ \\
\hline 3 & Bv & light brown homogeneous horizon, decalcified, some fine pores \\
\hline 4 & Cc & light yellow calcareous loess; bio-traces, small Mn-concretions, \\
\hline 5 & NB & Concentric iron oxide rings around root channels, pseudomycelia, bleached grey stains, scattered fine pores \\
\hline 6 & NB & light brown loess, diffuse iron oxide patches, pseudomycelia, small Mn-concretions, stained, \\
\hline 7 & & loess \\
\hline 8 & & reddish loess [fine dispersed iron oxides] \\
\hline 9 & & weak linear iron oxides on a pale matrix, calcareous nodules, lower limit marked by a strong line of iron oxides \\
\hline 10 & NB & $\begin{array}{l}\text { calcareous nodules, dark grey, many fine pores, loamy, 10\% calcium carbonate, molluscs, soil structure, iron oxide stains, } \\
\text { clearly limited, undulating lower boundary }\end{array}$ \\
\hline 11 & & bedded loess derivate with calcareous nodules and small Mn-concretions \\
\hline 12 & $\mathrm{fBv}$ & $\begin{array}{l}\text { no stratified loess, homogenous material, small globules of iron oxides, greyish brown colour, many pseudomycelia, } \\
\text { undulating lower boundary }\end{array}$ \\
\hline 13 & & stratified material, hydromorphic features \\
\hline 14 & NB & iron oxides diagonally ruled, big Mn-stains in the lower part \\
\hline 15 & & stratified loess derivates, strong reworked material \\
\hline 16 & fCcv & some calcareous nodules, sporadically little stones \\
\hline 17 & & massive slight pale yellow calcareous loess with fine iron oxide bands \\
\hline 18 & & loess derivate with many $\mathrm{Mn}$ - and iron oxide concretions \\
\hline 19 & & grey brownish loam, bands of iron oxides and small calcareous concretions \\
\hline 20 & $\mathrm{fG}$ & $\begin{array}{l}\text { grey, bleached material, locally patches of turquoise clay, bottle-like iron oxide concretions [often formed like a sugar } \\
\text { loaf] }\end{array}$ \\
\hline 21 & {$[\mathrm{fBv}]$} & [soil sediment] reddish brown loam, compact bedding, sometimes with weak platy microstructure \\
\hline 22 & & very massive layer, many stones, grey matrix with interfacial skins of iron oxides \\
\hline
\end{tabular}

Tab. 3: Description of section Zehren.

Tab. 3: Profilbeschreibung Zehren.

\begin{tabular}{|c|l|l|}
\hline Layer & Label & Description \\
\hline 1 & Ap & calcareous humic dark grey plough horizon \\
\hline 2 & & calcareous light yellow loess \\
\hline 3 & NB & carbonate enrichment, some light grey bleached stains, patches and bands of iron oxides, biotraces \\
\hline 4 & & loess with calcareous nodules \\
\hline 5 & fBvc & light brown yellowish loess, the upper boundary is marked by clearly visible and shredded layer of yellow material, \\
\hline 6 & & band of iron oxides on a grey yellowish bleached matrix \\
\hline 7 & & light brown yellowish loess, lower boundary is also marked by a shredded layer, pseudomycelia \\
\hline 8 & & loess with a fine layer of bleached patches, some pseudomycelia and iron oxides stains in the lower part \\
\hline 9 & NB & dark grey loamy material, clear lower and upper boundary, some iron oxides and a very fine angular structure, \\
\hline 10 & & stains of iron oxide, bleached root channels \\
\hline
\end{tabular}




\begin{tabular}{|c|l|l|}
\hline 11 & & laminated loess with biotraces, in the lower part Mn-concretions \\
\hline 12 & fBvc & light brown greyish material [not laminated!], small nodules of iron oxides \\
\hline 13 & & laminated loess with microcryoturbation \\
\hline 14 & fBvc & $\begin{array}{l}\text { brown greyish homogeneous material, iron and Mn-concretions, pseudomycelia, biotraces, clear iron oxide bands on the } \\
\text { lower boundary }\end{array}$ \\
\hline 15 & & loess \\
\hline 16 & NB & lightly grey bleached loess with iron oxide stains, clearly band of iron oxide \\
\hline 17 & & material showing weak lamination \\
\hline 18 & & light brown colouring \\
\hline 19 & & weakly laminated loess derivates \\
\hline 20 & & loess with distinct lamination and some iron oxides stains in the lower part, cryoturbation features \\
\hline 21 & fS/Bv & brownish grey loam with iron oxide grid, big Mn-patches, \\
\hline
\end{tabular}

Tab. 4: Description of section Ostrau.

Tab. 4: Profilbeschreibung Ostrau.

\begin{tabular}{|c|c|c|}
\hline Layer & Label & Description \\
\hline 1 & Bt & lower part of truncated Bt-horizon of the Holocene Luvisol, spare hydromorphic features [iron oxide stains] \\
\hline 2 & LFZ & short brown bands of loamy clayish material alternating with pale yellow loessic stains [lenticular horizon] \\
\hline 3 & Bv & homogeneous pale brown material, some diffuse cloud-like Mn-stains \\
\hline 4 & $\begin{array}{l}\text { NB [Nassboden } \\
\text { [germ] Gelic } \\
\text { Gleysol] }\end{array}$ & $\begin{array}{l}\text { typical microstructure of loess, slightly brown colour, some parts show pale dark discolouration when the } \\
\text { surface is drying; these discolourated parts look like filled earthworm burrows [current work determination: } \\
\text { bio-traps], sporadic Mn-concretions }\end{array}$ \\
\hline 5 & NB & $\begin{array}{l}\text { dark grey bleached loamy material with rust stains and a clear microstructure [rough section surface after } \\
\text { preparation], } \mathrm{CaCO}_{3} \text {-concretions make crunching noise when cleaning the section, calcareous nodules } \\
\text { horizontally bedded }\end{array}$ \\
\hline 6 & & laminated loess derivate, sparely iron oxides stains \\
\hline 7 & $\mathrm{fBv}$ & $\begin{array}{l}\text { light dark, pale brown [slightly purplish] colour; calcareous nodules, very distinct lower and upper boundary } \\
\text { [undulating], } \\
\text { rust stains, pseudomycelia, Mn-concretions; cryoturbation features }\end{array}$ \\
\hline \multirow[t]{2}{*}{8} & & laminated loess derivate, in the lower part big Mn-stains \\
\hline & & stronger reworked material - clear changes in texture \\
\hline 9 & $\mathrm{fS} / \mathrm{Bv}$ & $\begin{array}{l}\text { thick layer; brown, slightly reddish [10YR6/4]; in the upper part stains of iron oxides [leopard skin-like], in } \\
\text { the lower part increase of bleaching and iron oxides, fissures are lined with iron oxides skins, sporadically } \\
\text { pseudomycelia; loamy, mixed with coarse fragments }\end{array}$ \\
\hline 10 & & bright yellow silt, without any features of pedogenesis, filled ice wedge \\
\hline 11 & & $\begin{array}{l}\text { clear boundary, grey matrix [10YR5/4] with fragments of reddish brown clayic material, relative high content } \\
\text { of coarse material and calcareous concretions, solifluction features }\end{array}$ \\
\hline 12 & reworked Bt & $\begin{array}{l}\text { dark yellowish [reddish] brown [10YR4/4] loam, sporadically angular structure, in the lower part strong } \\
\text { hydromorphic features [grey bleached] }\end{array}$ \\
\hline 13 & $\mathrm{HZ}$ & dark pale grey brown silt [mottles], least compacted \\
\hline 14 & $\mathrm{fS}[\mathrm{e}] \mathrm{w}$ & conspicuous bright grey material; loose structure; charcoal; big fibril Mn-concretions \\
\hline \multirow[t]{2}{*}{15} & $\mathrm{fSw} / \mathrm{Bt}$ & $\begin{array}{l}\text { mottled yellow reddish orange horizon, bleached grey root channels subangular structure, in-situ Bt-horizon } \\
\text { of a Luvisol with hydromorphic features }\end{array}$ \\
\hline & & buried stone layer \\
\hline 17 & & sand with clay coatings and a prismatic structure, intense reddish colour \\
\hline
\end{tabular}

HZ - Humuszone (humic horizon) 


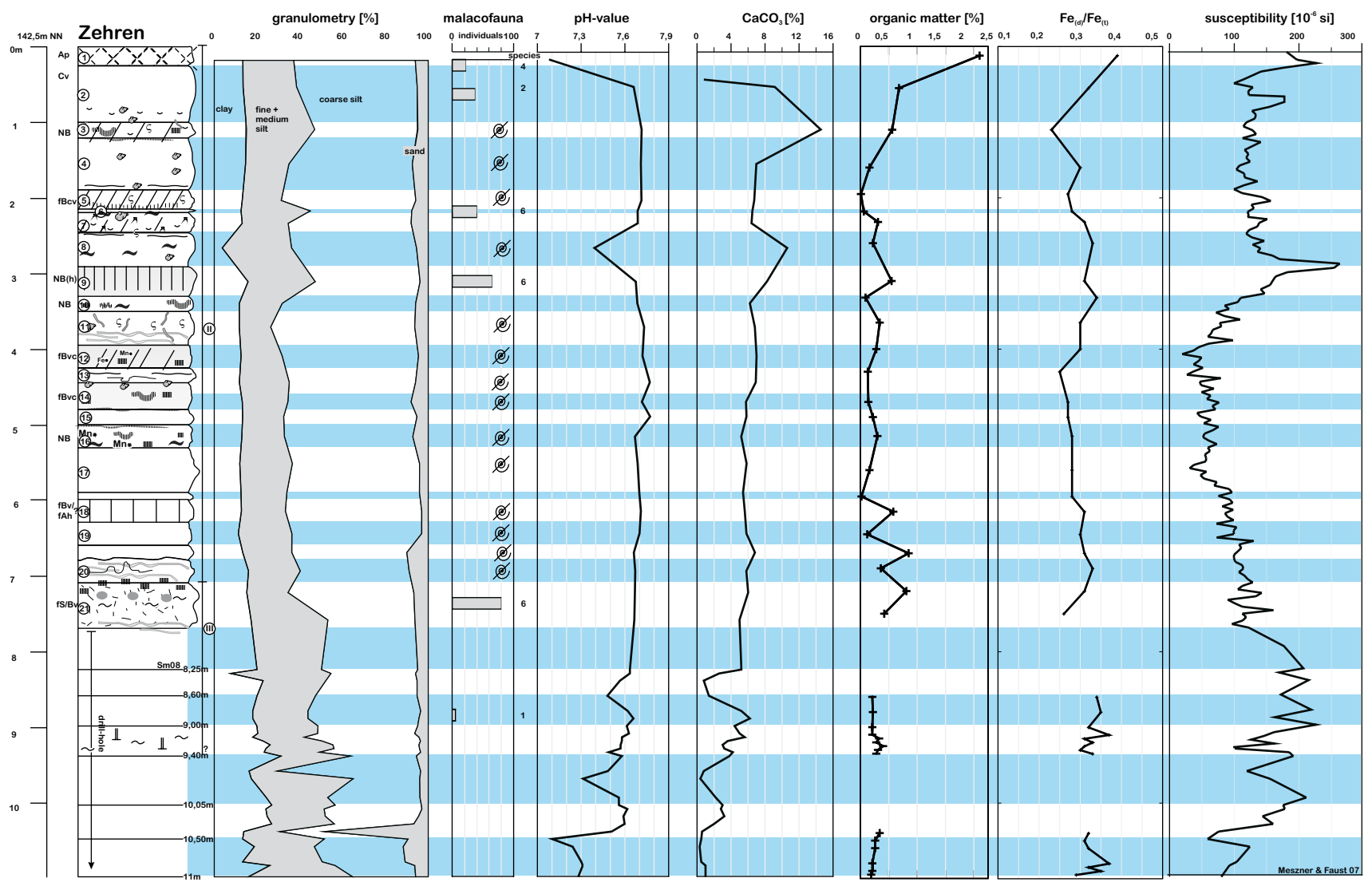

Fig. 6: Profile Zehren with geochemical results.

Abb. 6: Profil Zehren mit den dazugehörigen geochemichen Analyseergebnissen.

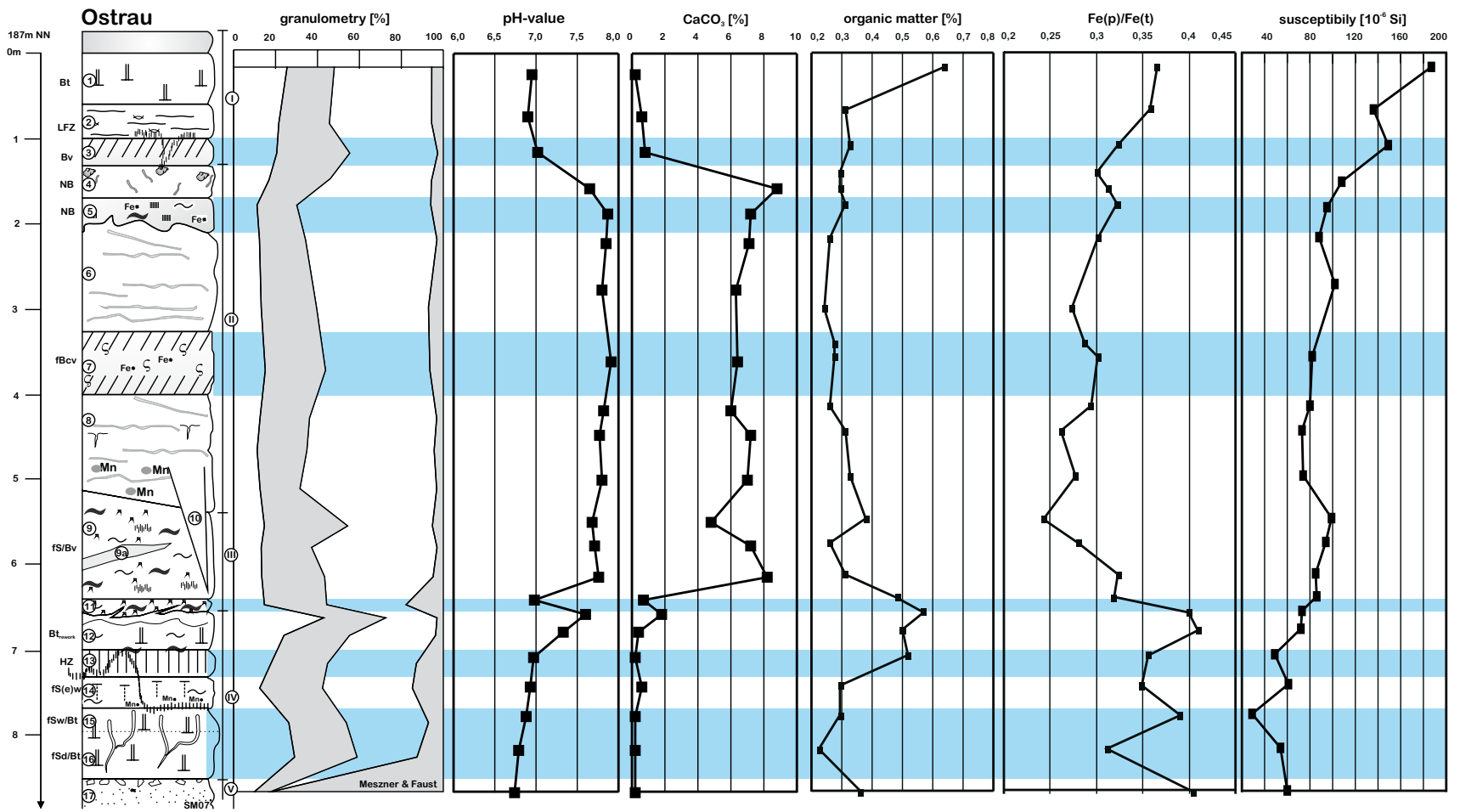

Fig. 7: Profile Ostrau with geochemical results.

Abb. 7: Profil Ostrau mit den dazugehörigen geochemichen Analyseergebnissen. 


\section{Ostrau}

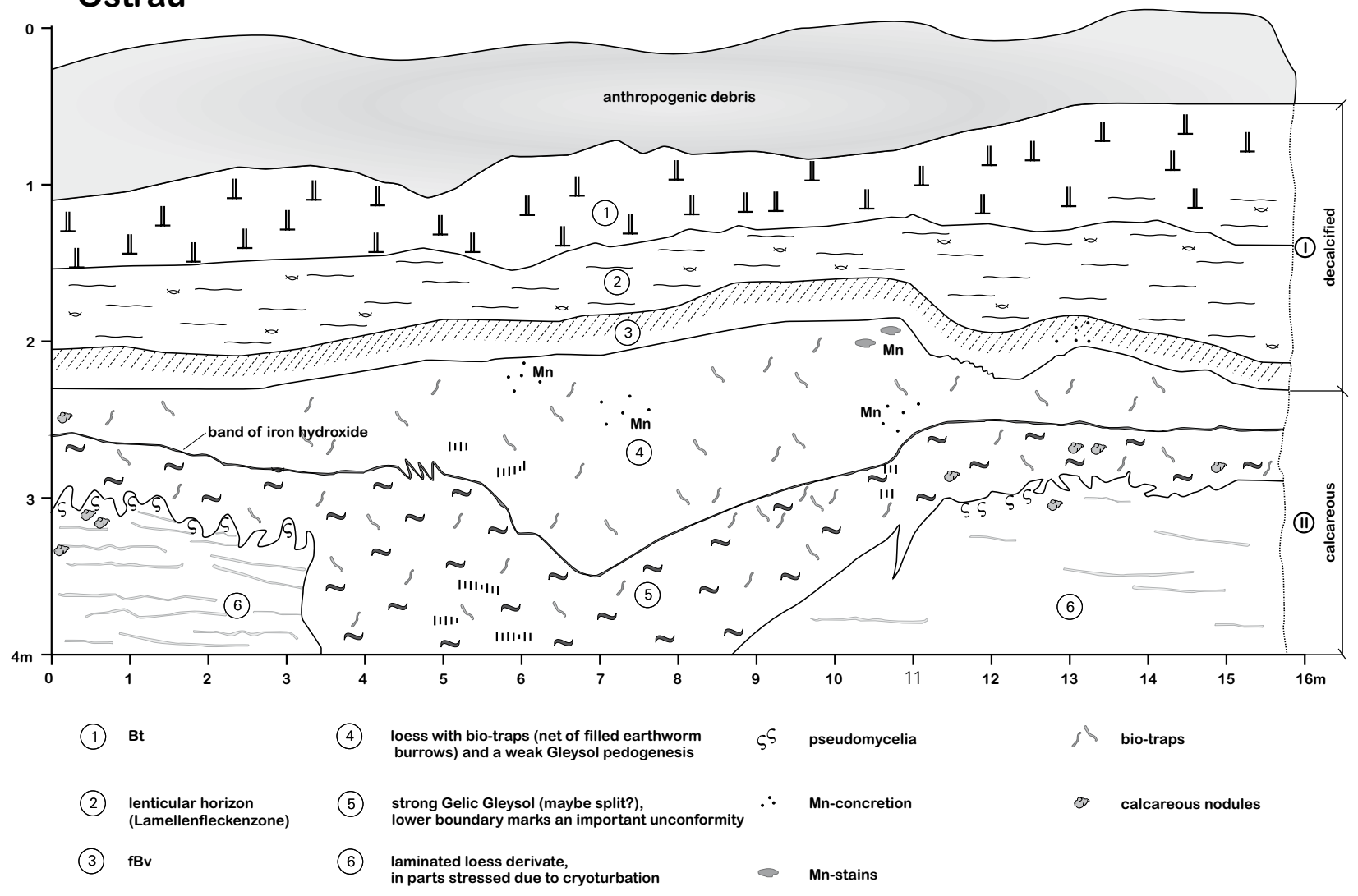

Fig. 8: Detailed draft of the upper part of section Ostrau.

Abb. 8: Detailzeichung des oberen Teils der Abbauwand im Profil Ostrau.

Tab. 5: Description of section Zschaitz.

Tab. 5: Profilbeschreibung Zschaitz.

\begin{tabular}{|c|c|c|}
\hline Layer & Label & Description \\
\hline 1 & Bt & $\begin{array}{l}\text { reddish brown clay enriched compact loam, weak pinprick structure and sporadically hydromorphic features [rust } \\
\text { stains] }\end{array}$ \\
\hline 2 & LFZ & $\begin{array}{l}\text { lamellar lined structure between brownish clay-enriched and yellowish coarse silt; in the upper part large and in the } \\
\text { lower part narrow bedding, lenticular horizon }\end{array}$ \\
\hline 3 & Bv & $\begin{array}{l}\text { homogeneous light brownish grey, non calcareous silt, loose loess structure; several dark greyish curved structures } \\
\text { [banana-like] crossing the boundary into the calcareous loess; boundary between non-calcareous and calcareous } \\
\text { loess }\end{array}$ \\
\hline 4 & NB & grey material, hydromorphic features, undulated lower limit \\
\hline 5 & & laminated material with small frost cracks \\
\hline 6 & $\mathrm{fBv}$ & platy structure, $\mathrm{Mn}$-concretions, pale grey-brown \\
\hline 7 & & loess \\
\hline 8 & $\mathrm{fBv}$ & Mn-concretions, pale grey-brown \\
\hline $8 a$ & & slightly reworked loess, laminated \\
\hline 9 & NB fBv/fG? & $\begin{array}{l}\text { homogeneous greyish material; increase content of fine to medium silt and clay; deoxidation in the lowest part of } \\
\text { this layer }\end{array}$ \\
\hline 10 & $\mathrm{fBv}$ & brown loessic material with fine dispersed iron-oxides \\
\hline 11 & & light yellow greenish layer with fibered $\mathrm{Mn}-[2-5 \mathrm{~mm}]$ and iron-oxide concretions \\
\hline 12 & $\mathrm{fG}$ & grey, bleached material, locally patches of turquoise clay, bottle-like iron oxide concretions \\
\hline 13 & $\begin{array}{l}\text { Bt } \\
\text { reworked }\end{array}$ & $\begin{array}{l}\text { reddish layer with high content of clay; constant thickness; microstructure; the lower limit is marked by a crusted } \\
\text { band of iron oxide; nearly no } \mathrm{Mn} \text {-concretions; thin horizontal patches of bleached material }\end{array}$ \\
\hline 14 & $\mathrm{fBt}-\mathrm{Sd}$ & $\begin{array}{l}\text { brown reddish, slightly purple material; well developed microstructure; bleached root channel, ice wedges are filled } \\
\text { with fBt-Sd-material }\end{array}$ \\
\hline
\end{tabular}




\begin{tabular}{|l|l|l|}
\hline 15 & IlfBtSd & variocoloured horizon, orange reddish and grey parts, many stones, grey bleached channels \\
\hline 16 & & very coarse material, many stones \\
\hline 17 & & gravel from a palaeochannel of the Freiberger Mulde river \\
\hline
\end{tabular}

Tab.6: Description of section Klipphausen.

Tab. 6: Profilbeschreibung Klipphausen.

\begin{tabular}{|c|l|l|}
\hline Layer & Label & Description \\
\hline 1 & Bt/Sd & checkered loam with clay filled root channels; bleached clay \\
\hline 2 & & yellowish loam with numerous Mn-concretions \\
\hline 3 & & deoxidized greyish loam with bottle-like iron-oxide structures \\
\hline 4 & & reddish, grey-brown clayish loam \\
\hline 5 & & loessic laminated silty loam, platy microstructure \\
\hline 6 & & homogeneous brown clayish loam, compacted \\
\hline 7 & & light grey loam; in the upper part some patches of iron-oxide; the lower limit is marked by crusted band of iron oxides \\
\hline 8 & & silty loam, yellow matrix with rusty coatings \\
\hline 9 & & sandy loam with grey bleached patches in a reddisch oxidized matrix \\
\hline 10 & & bedded sand, upper limit is marked by a distinctive Mn-band \\
\hline
\end{tabular}

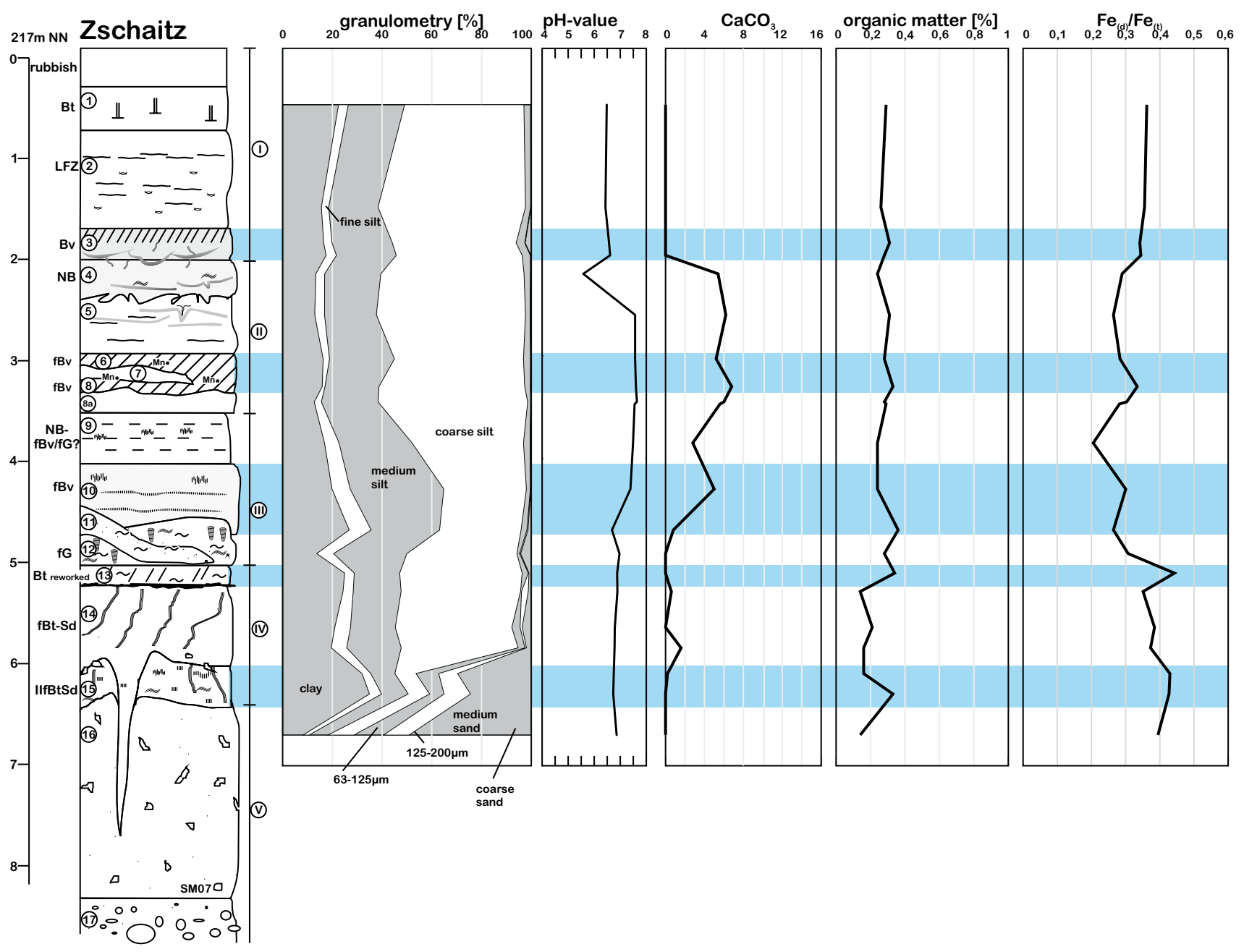

Fig. 9: Profile Zschaitz with geochemical results.

Abb. 9: Profil Zschaitz mit den dazugehörigen geochemichen Analyseergebnissen. 


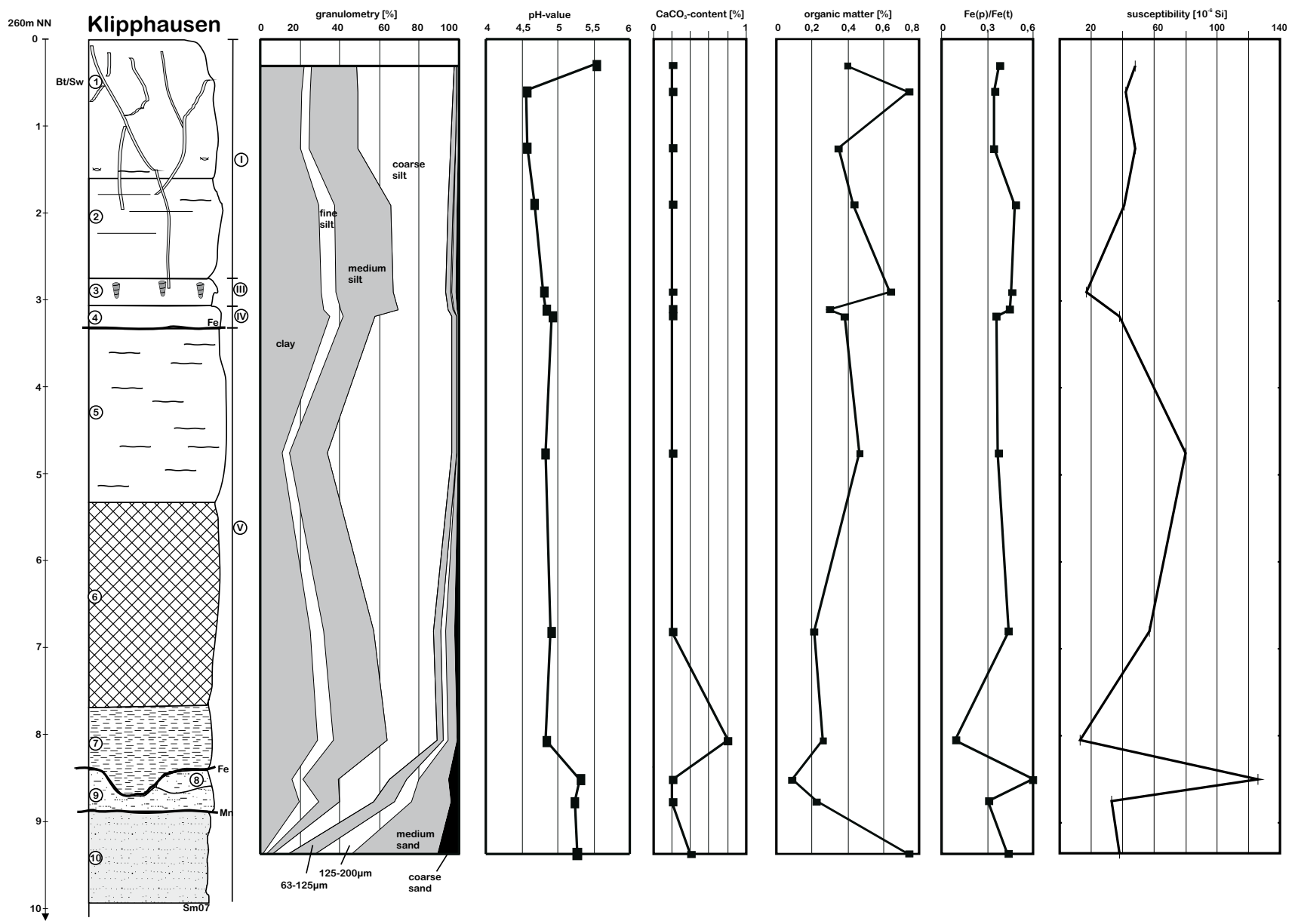

Fig. 10: Section Klipphausen (contrary hachures to fig. 16 in layer 6-10!: 6 - clayic loam; 7 - light grey loam; 8 - silty loam; 9 - sandy loam; 10 - bedded sand). Abb. 10: Profil Klipphausen (von der Legende (Abb. 16) abweichende Schraffuren in Schicht 6-10!: 6 - toniger Lehm; 7 - hellgrauer Lehm; 8 - schluffiger Lehm; 9 - sandiger Lehm; 10 - geschichteter Sand).

Tab. 7: Description of section Gleina.

Tab. 7: Profilbeschreibung Gleina.

\begin{tabular}{|c|l|l|}
\hline Layer & Label & Description \\
\hline 1 & Bt & lower part of the truncated Bt-horizon \\
\hline 2 & LFZ & lenticular horizon \\
\hline 3 & Bv & homogeneous pale brown decalcified horizon \\
\hline 4 & & bleached stains [root channels], biotraps, at the lower part slightly brown with Mn-stains \\
\hline 5 & NB & high porosity, many bleached stains, bright orange iron oxide rings around filled root channels \\
\hline & & loess with many iron hydroxide stains \\
\hline 6 & NB & many small calcic nodules [Loesskindl]; bleached, the lower part shows many Mn-dots \\
\hline 7 & NB & loess, scattered small Mn-concretions, scarcely iron hydroxide stains \\
\hline 8 & & calcareous nodules, strong bleaching; scattered rust stains, platy structure, clear boundaries \\
\hline 9 & NB & laminated loess derivate, loose density \\
\hline 10 & & weak bleaching; homogeneous [not laminated], iron hydroxide stains, pseudomycelia \\
\hline 11 & fBv & laminated material with small frost cracks, loess derivates \\
\hline 12 & & homogeneuos, diffuse distributed iron hydroxide stains, pseudomycelia; loamy, weak structure, many pores \\
\hline 13 & fBv & weak laminated material with features of cryoturbation stress \\
\hline 14 & & pseudomycelia; no lamination, gathering of Mn-stains, small iron hydroxide concretions \\
\hline
\end{tabular}




\begin{tabular}{|c|c|c|}
\hline 15 & & $\begin{array}{l}\text { transition zone between weakly modified and strongly reworked loess, } \\
\text { above: many oval Mn-stains } \\
\text { beneath: bigger Mn-stains, compact structure, loamy, typical iron oxide grid [leopard skin-like] }\end{array}$ \\
\hline & & increasing of medium and fine silt with depth, big Mn-stains with diffuse boundaries \\
\hline 16 & & Mn-stains and calcareous nodules, location of big $[15 \mathrm{~cm}]$ horizontal bedded calcareous nodules \\
\hline 17 & & $\begin{array}{l}\text { increasing clay content with depth, scattered iron hydroxide stains, in the depth of } 10.30 \text { m gradual increase } \\
\text { of carbonate, small admixture of coarse fragments; the lowest part is represented by a brown greyish } \\
\text { clayish layer }\end{array}$ \\
\hline 18 & fG & $\begin{array}{l}\text { non calcareous, intense bleached, grey horizon }[10 \mathrm{BG} 6 / 1] \text {; the lower boundary is marked by intense lines of } \\
\text { iron hydroxides }\end{array}$ \\
\hline 19 & $\mathrm{fBv}$ & reddish brown horizon, platy structure, bands of iron hydroxide that end abruptly at the upper boundary \\
\hline 20 & & gradually decrease of carbonate, bedded structure with embedded sandy lenses \\
\hline 21 & $\mathrm{HZ}$ & dark pale grey brown silt, least compacted \\
\hline 22 & fS[e]w reworked & $\begin{array}{l}\text { bright grey bleached material, weak coherence, big Mn-concretions }[0.5-1 \mathrm{~cm}] \text { often with fibril structure; } \\
\text { charcoal! }\end{array}$ \\
\hline 23 & IIfS[e]w & intense mottles of reddish brown iron hydroxides, most parts are bleached, subangular structure; \\
\hline 24 & $\mathrm{fBtSd}$ & $\begin{array}{l}\text { intense bleached root channels, clearly subangular structure, decrease of colouring, in the lower part more } \\
\text { reddish, more darkish at the top }\end{array}$ \\
\hline 25 & $\begin{array}{l}\text { IIfBt }_{\text {[Sand }]} \\
\text { IIIfG }_{[\text {silt }]}\end{array}$ & mixed layer with reddish clay and light gray silt \\
\hline 26 & & light ochre sand \\
\hline
\end{tabular}

Of particular interest is the humic horizon in layer 13 and the bleached lower part rich in charcoal remnants (layer 14). In Ostrau this stratigraphically lowest unit is composed of Saalian deposits in which two in situ horizons were formed (Eemian soil; layer 15/16).

\subsection{Section Zschaitz [Tab. 5; Fig. 9]}

At the Zschaitz section deposits of an ancient river branch of the Mulde river (EISSMANN, 1964) are exposed in a gravel pit (GK R 4580416 H 5669191). These fluvial deposits are covered by loess sediments of two glacials. Four units could be identified in this section. Details are given in Tab. 5 . Unit I is composed of decalcified sediment layers which could be correlated with almost all the other sections described in the present study. The lower boundary of this unit is marked by the boundary of the decalcified layer into the calcareous loess. Unit II is not as distinct as in the other sections and composed of the layers 4 to $8 \mathrm{a}$. Unit III contains several soil sediments and solifluction layers. Its boundary to unit IV is distinct and clear. Unit IV has on its top remnants of the last interglacial soil. The deeper part shows big ice wedges and strongly reworked loess derivates with little gravel content. Within this deepest layer (16) close to the contact to the gravel deposits (layer 17) some artifacts (small bifaces) were found but have not been investigated yet.

\subsection{Section Klipphausen [Tab. 6; Fig. 10]}

This section is situated close to the village of Klipphausen (GK R $4605947 \mathrm{H} \mathrm{5660667).} \mathrm{It} \mathrm{is} \mathrm{not} \mathrm{accessible} \mathrm{anymore} \mathrm{be-}$ cause it existed only for a short period of time during house construction. The section Klipphausen is characterized by an additional pattern, not identified in the above described sections. The material of the upper three meters is loamy (20\%-60\% clay; fine and medium silt) and show a low $\mathrm{pH}-$ value. This is due to the fact that this section is located in the southern part of the study area close to the connecting slope into the southern mountain range (Erzgebirge). It is a typical position for the transition zone from the loess plateau with eolian dominated processes into the mountain landscape which was dominated by solifluction processes. The section is composed of different layers including loess derivates and solifluction layers. We only see similarities according to the other sections in the upper part of this sequence. There, gleyic features are found in a loess derivate (layer 3) which we correlate with layer 16 of the Leippen section (Fig. 2) and layer 20 of the Seilitz section (Fig. 4).

\subsection{Section Gleina [Tab. 7; Fig. 11]}

The Gleina section is located at the northern loess boundary (Lössrandstufe) at the western edge of the village Gleina (GK $\mathrm{R} 4586889 \mathrm{H}$ 5678057). This former brickyard is the type locality for the so called "Gleinaer Bodenkomplex" which is an interstadial soil complex (LIEBEROTH \& HAASE, 1964).

The Gleina section was reopened by us in 2009. Fig. 11 shows the main stratigraphical units. The thick loess sequence of Gleina has comparable units which correlate well with the previously described profiles. The four important units already described are present in this section. The section also shows the "Gleinaer Bodenkomplex", which is easy to identify because of its intense colour changes from gray to reddish. In addition, this soil complex is characterized by its decalcified horizon between the top of the complex and the following interglacial soil below. However, in all the other sections, there is no clear evidence of this complex.

According to Neumeister (1966) who reported the thickest 


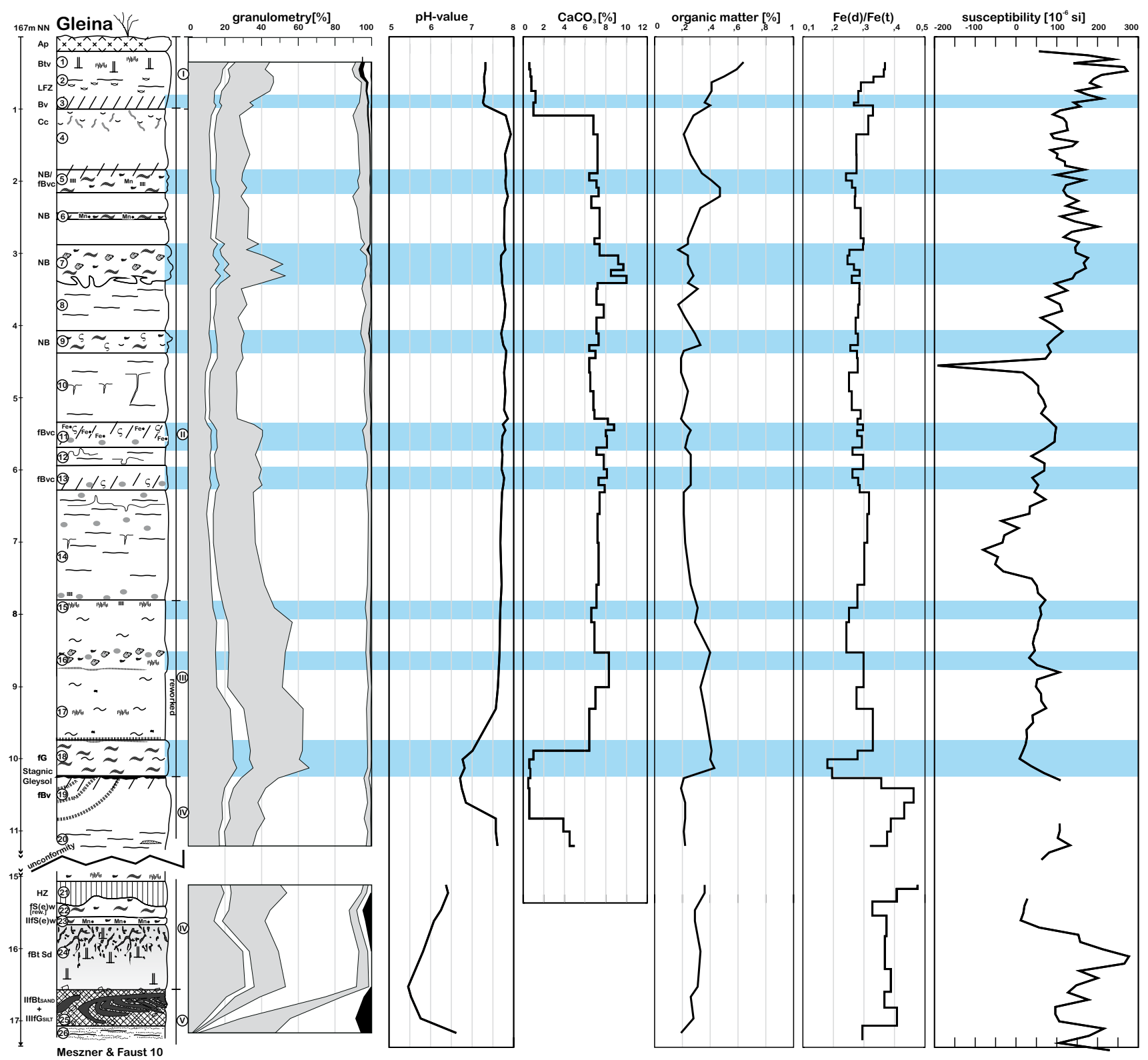

Fig. 11: Profile Gleina with geochemical results.

Abb. 11: Profil Gleina mit den dazugehörigen geochemichen Analyseergebnissen.

Weichselian loess layers in the northern boundary (Lössrandstufe) our findings show a similar pattern. The northernmost sections (Gleina and Zehren) show the thickest, and in the case of Gleina most complete Weichselian loess deposits. In contrast, the section Klipphausen, situated at the southern boundary of the loess plateau, shows only Weichselian loess deposits of $3 \mathrm{~m}$ thickness.

\section{Interpretation and discussion}

The main lithological and pedogenical features of all studied sections are used to establish a standard loess-palaeosol profile for the Saxonian loess region. In five sections (Leippen, Seilitz, Ostrau, Zschaitz, Gleina) the uppermost $2 \mathrm{~m}$ look almost similar. The material is decalcified and in the uppermost part a luvisol was formed during the Holocene. Below a well-developed Btv-horizon a lenticular horizon ("Lamellenfleckenzone" after LIEBEROTH, 1959) can be observed in all sequences. In some cases ice wedges just below the recent surface were formed and whose infilling show lenticular structure even if they reach into the underlying horizon. We assume that this widespread lenticular horizon was formed after a strong cooling which generated these ice wedges. The features of lenticular structure point to a pedogenesis which can be explained by alternations between frozen and unfrozen conditions, resulting in clear band shaped structures of different grain sizes. The underlying horizon is not affected by this process and shows no banded features (Fig. 12). We suggest a taiga like environment to form such features. Below the lenticular horizon of the former permafrost horizon a brownish palaeosol is preserved. At the lower boundary of the brownish palaeosol there is a change from decalcified to calcified loess. This distinct change in the carbonate content represents a clear horizontal boundary, which is hard to identify in the sections. All these findings belong to unit I (Fig. 14) and are in consistency with former studies (HAASE et al. 1970; LiEBEROTH 1959, 1962a, 1962b, 1963). 
Unit II is a loess layer up to $7 \mathrm{~m}$ thick. Except for some palaeosols within this unit, the loess shows only minor evidences of reworking. Unit II contains at least four palaeosols, including two weak soils showing gelic Gleysol features.

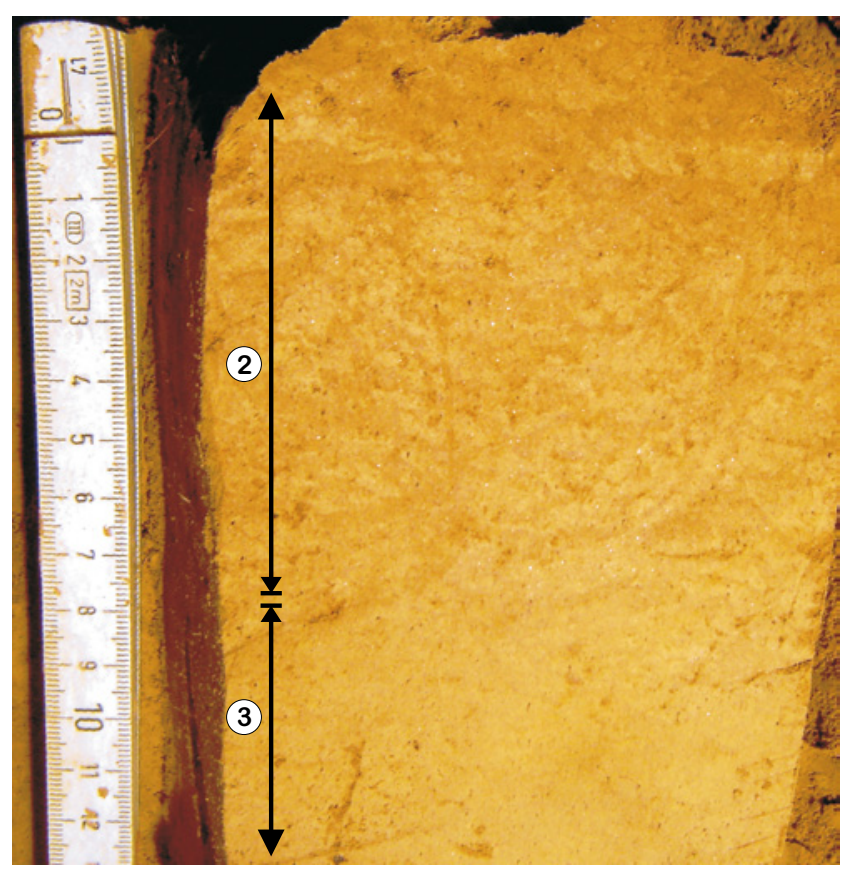

Fig. 12: Close up view of the lenticular (2) and underlying Bv-horizon (3) from Seilitz section (Photo: S. Meszner).

Abb. 12: Detailaufnahme des unteren Teils der Lamellenfleckenzone (2) und des Bv-Horizontes (3) oberhalb der holozänen Entkalkungsgrenze aus dem Profil Seilitz.

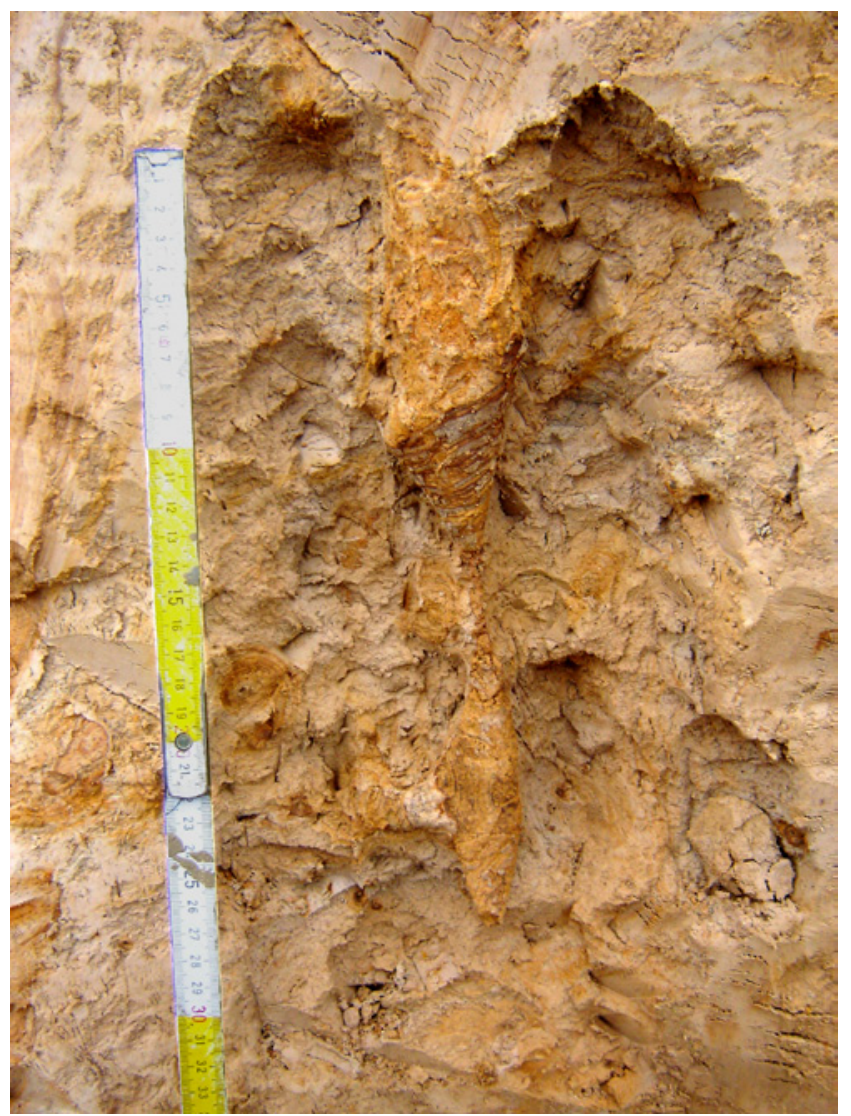

Fig. 13: Bottle-like iron oxide concretion in the section Seilitz.

Abb. 13: Flaschenähnliche Eisenkonkretionen im Profil Seilitz.
One of the strong soils can be characterized as a Cambisol, the other ones are reworked greyish gelic Gleysols with elevated humic content (Fig. 4 and 6). At the Zehren section mollusk analyses were conducted showing a high number of individuals of several species in the reworked humic gelic Gleysol. In contrast to the pedological features showing gleyic conditions the mollusk analyses point to a steppic palaeoenvironment. The occurrence of Cecilioides acicula indicates drier climatic conditions during the formation of this horizon (HAMANN, 2010 unpub.). This horizon is most likely of polygenetic origin, assuming humid conditions, which led to the formation of a gelic Gleysol. Later this gelic Gleysol was reworked, also documented in the Ostrau section with features of deep gullying. SCHIRMER (2000) described a similar situation from the lower Rhine loess region and termed this layer "Eben-Zone". It is possible that erosion and redistribution of sediments were widespread during this period. A IRSL-sample from the top of this gelic Gleysol in Leippen section is dated to an age of $21.6+/-2,5 \mathrm{ka}$ (Fig. 2).

In a next stage subsequent soil formation under drier conditions took place. A humic horizon was formed within the material of the reworked gelic Gleysol in which the mollusk assemblage developed. Antoine et al. (2009) describe comparable processes. The humic soil formation correlates to a short interstadial with slightly drier climatic conditions. At section Zehren and Seilitz these soil horizons have higher magnetic susceptibility values. These two strong palaeosols can be identified in five out of seven profiles and interpreted as characteristic marker soils. The more weakly developed palaeosols can be observed in three sections (Seilitz, Zehren, Gleina). In contrast, former studies by HAASE et al. (1970) and Lieberoth (1959, 1962a, 1963) describe only one weak soil within this unit II instead of two strong and one weak palaeosol which we could identify for Unit II of the composite Saxonian loess sequence. Numerical dating at the basis of Unit II in the Leippen section shows an IRSL-age $26.4+/-3 \mathrm{ka}$ (Fig. 2).

The structure of unit III is complex but differs significantly from the overlying unit because of a shift in terms of granulometric composition from silt dominated material in the overlying unit II to more loamy material in unit III. This unit shows clear evidences of reworking processes. Coarse silt decreases whereas clay, fine silt, and medium silt as well as the sand fraction increase. Some parts of unit III are also characterized by a certain content of small pebbles of $1 \mathrm{~cm}$ in diameter as seen in the sections of Leippen, Seilitz, Zehren and Ostrau (Fig. 2, 4, $6 \&$ 7). In the upper part of the transition zone large dark manganese spots (lowest part of unit II) could be observed. Iron oxide patterns are abundant in the lower part (uppermost part of unit III). In terms of climatic conditions it is assumed that the transition shows a climatic change from more arid conditions (unit II) to more humid conditions (upper part of unit III). Unit III shows in the part beneath very clear features of solifluction with incorporated small pebbles in an unsorted material. According to HAASE et al. (1970) and Koch $\&$ Neumeister (2005) the material shows properties of loess derivates that is varicoloured.

Beneath the varicoloured loess derivate we observe a grey hydromorphic solifluction layer that shows clear features of cryoturbation with bottle shaped struc- 


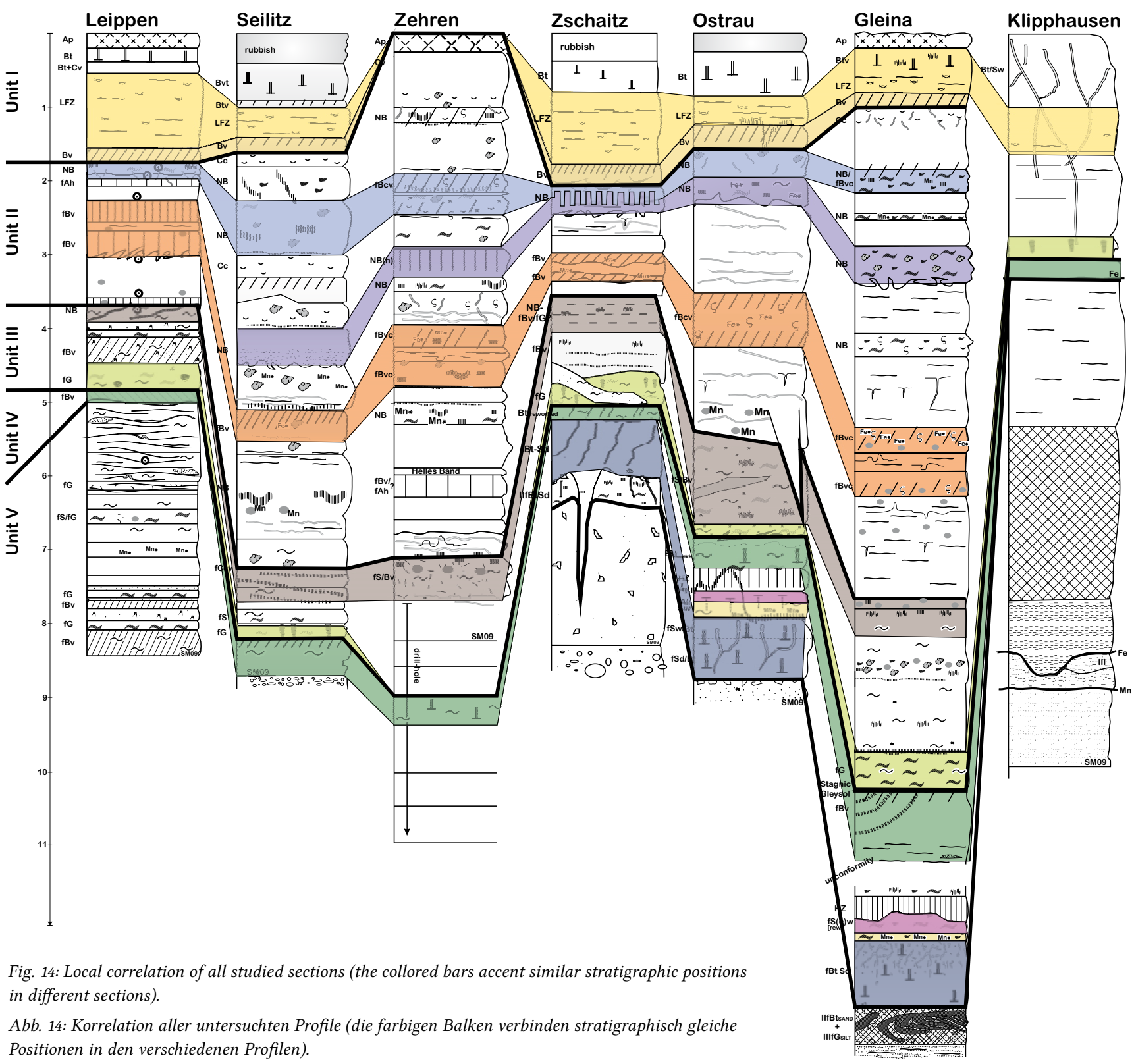

ture (Fig. 13). These features named "Roströhrengley" by LieBeroth (1963) can be seen in every section. The formation of this "Roströhrengley" is supposed to have been taken place during a cold and moist climate. This soil-like material (Roströhrengley) is integrated in the "Gleina Soil Complex" (Lieberoth, 1963). The Gleina Soil Complex contains furthermore an arctic brown soil below the gley soil that indicates slightly better climatic conditions. This complex is easy to identify by studying the graph of the ironoxides ratio. The gley soil is mark by a profil-wide minimum of the $\mathrm{Fe}(\mathrm{d}) / \mathrm{Fe}(\mathrm{t})-$ ratio as can be seen in the sections Seilitz, Gleina, and Leippen. In contrast the underlying arctic brown soil is characterized by an increase of this ratio (Seilitz 21, Zschaitz 13, Ostrau 12, Gleina 19, Leippen 17). In the sections Gleina and Ostrau the values of iron-oxide ratios exceed in the reddish brown soil (arctic brown soil) the values of the Holocene and Eemian interglacial soils. Comparing these data we suppose a high activity of iron oxides caused by high oxidation-reduction potential during the formation of this interstadial complex.

In all sections, the arctic brown soil shows a reworked structure, whereas at the Gleina section this brown arctic soil was formed "in situ" however superimposing a reworked brown arctic soil sediment. This is proved by the fact that a distinct platy soil structure is developed.

LiEBERoth (1962a) assumed that the "Gleina Soil Complex" was formed at the same time as the "Lohne Soil" (SEMMEL, 1968) respectively the "Paudorf Soil" (FINK, 1964). We do not support this interpretation because our findings point to a much older formation of the lower part of the "Gleina Soil Complex". This is supported by the observation that the lower part of unit III and the upper part of unit IV shows changes in terms of granulometric composition even between the "Roströhrengley" and the reworked arctic brown soil. Unconformities between unit III and IV in some sections indicate that prior to the formation of the "Roströhrengley" erosion and sedimentation took place. Finally it suggests a correlation of this soil complex ("Roströhrengley" and reworked arctic brown soil beneath) with the "Niedereschbacher Zone" described by SEMMEL (1968). It seems that processes of landscape disturbances and redistribution of soil material are typical for the Middle Weichselian in Saxony. 


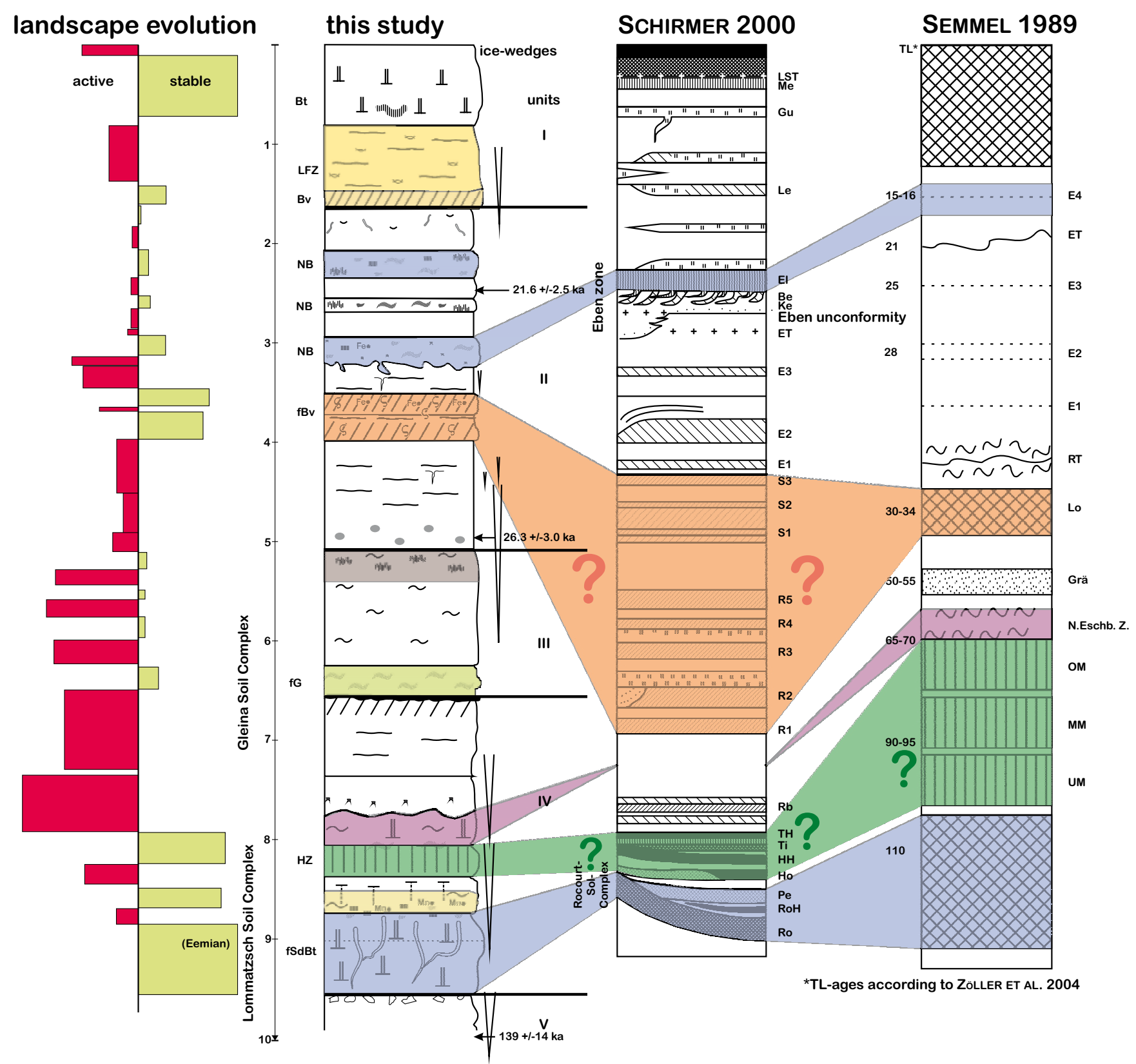

Fig. 15: Composite profile of Saxony and regional correlation with other loess areas in central Europe.

Abb. 15: Standardprofil der mittelsächsischen Lösse und mögliche Korrelation mit anderen Lössgebieten Mitteleuropas.

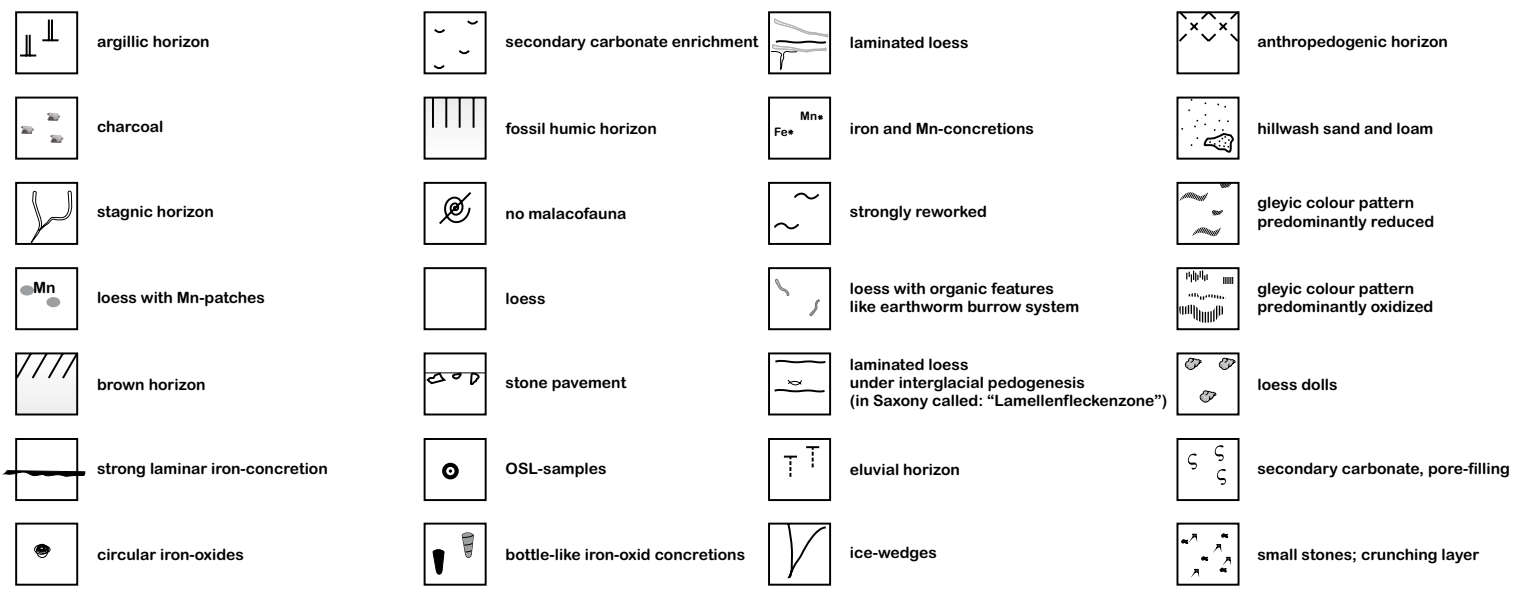

Fig. 16: Legend for all profile drawings presented in this study.

Abb. 16: Legende, für alle in dieser Arbeit verwendeten Profilskizzen. 
Unit IV is only exposed at the sections of Ostrau, Gleina and with some modifications at the setting of Zschaitz. Compared to the unit above we observe only in the upper part reworking of soils in this unit. The reworked arctic brown soil is the result of a period of soil formation, followed by a period of solifluction. The increase of clay content and pedogenetic iron content $\left(\mathrm{Fe}_{\mathrm{d}} / \mathrm{Fe}_{\mathrm{t}}\right)$ denote this soil formation. Obviously the arctic brown soil formed within material most probably eroded from the Eemian soil (OIS-5e). In section Gleina (Fig. 11) we observe a gradually increase of colour to the top of the arctic brown soil (layer 19) and a clear unconformity to the overlaying redeposited "Roströhrengley".

Most of the soils of unit IV are formed in situ. However, some soil-(sediments) show weak features of a short relocation. After deposition this material underwent soil formation. At the Ostrau section, the upper part of unit IV contains a humic soil that is preserved as well as at the section of Zschaitz, however slightly reworked. LieBERoth (1963) did not mention humic soils in this stratigraphic position although he described many profiles in Saxony. The occurance of such humic soils was reported from drier regions (e.g. Thuringian Basin and Harz foreland) by Ruske et al. (1962), Ruske \& WüNSCHE (1964a, 1964b), SEmmel (1968), and Schönhals et al. (1964). In accordance to these findings we postulate drier conditions during the formation of this humic soil in our study area.

Below the humic soil a pale soil sediment is present which can be observed in all sections, even if there has no humic horizon been found. This layer is supposed to be the earliest Weichselian deposit. The most obvious feature of this layer is the abundance of large manganese concretions. At sections Seilitz, Ostrau and Gleina this lowest part of unit IV is intermingled by these concretions and charcoal pieces. Macro remnant analyses of 25 pieces indicate, that only Larix decidua MiLl. was found. It seems that at the end of the Eemian Interglacial and during the transition time towards the Early Weichselian a larch forest covered the landscape.

In the study area an Eemian soil (Pseudogley) is preserved below the Weichselian loess deposit at the sections of Ostrau, Zschaitz and Gleina. At all other profiles the lower boundary of the Weichselian loess can be hardly defined. The differences between an early Weichselian rebedding or a late Saalian rebedding is almost impossible because both layers show similar colouring and grain size distribution. Especially the grain size distribution varies in these layers in short interval (e.g. profile Leippen).

\section{Conclusions}

In order to develop a reliable stratigraphy, seven loess-palaeosol profiles were studied in detail and further profiles were discussed for comparison. Based on these investigations a high-resolution composite profile was compiled.

\subsection{Local correlation}

Fig. 14 shows an overview of all studied sections. The colour-bars represent correlations between the individual sections, based on lithological and palaeopedological analyses. Three IRSL-ages are provided for a first chronostratigraphic interpretation. Most of the sections to the north of the studied Saxonian loess plateau (Gleina, Zehren, Seilitz) are char- acterized by thick accumulations of loess with intercalated palaeosols. The sections Leippen and Zschaitz situated in the south of the Saxonian loess plateau show much less accumulations of loess, representing the general north-south trend of loess thickness.

\subsection{Composite profile [Fig. 15]}

According to our results a detailed composite profile (Fig. 15) for the Saxonian Loess Area is proposed. Main contributions to the findings of HAASE et al. (1970) and LIEBEROTH (1963) are two strong soils and two weak soils formed within unit II. We consider the Gleina Soil Complex not to be correlated with the Lohne Soil Complex as proposed by LIEBERoTH (1962a, 1963) and Ricken (1983).

Another important feature that was not described in former studies is the humic horizon just above the Eemian soil complex. We correlate this humic horizon with one of the "Mosbacher Humuszonen" as described by SEMmEL (1997a, 1997b) and with the humic parts of the Rocourt-SolComplex by SCHIRMER (2000), respectively.

Ice wedges point to strong cold events without thick snow cover. Some of the ice wedges are even incised into lower units. In unit II the big ice wedges show a marginal bulge that indicate a longer phase of very cold winters. To form a marginal bulge of the ice wedge frequent changes of melting and strong freezing are necessary. The sequence is characterized by changes of soil formation, loess deposition and solifluction. These features are interpreted (left graph of Fig. 15) in terms of geomorphic conditions and landscape evolution. Stable conditions coincide with periods of soil formation, whereas geomorphic activity can be attributed to loess deposition or solifluction. The latter takes place in transition phases in terms of climatic conditions. Ice wedges indicate strong dry cooling events.

Two composite profiles of the western part of Germany (SEMmEl 1989; ZöLLER et al. 2004; SCHIRMER 2000, 2004) are added to the Saxonian composite profile in order to correlate similar findings into a chronostratigraphic approach. The very detailed analyses of the Nussloch section (BIBus et al. 2007; ANTOINE et al. 2001) are considered as well, however because of its high resolution it does not serve for overview comparison.

\section{Acknowledgements}

We would like to thank the Deutsche Forschungsgemeinschaft (DFG) for supporting this project (FA 239/13-1). Thanks to Carolin Hamann for mollusk analyses and to Andrea Seim for macro remnant analyses on charcoal pieces. For helpful comments, we are most thankful to Ludwig Zöller and Arno Semmel. The authors wish to thank their colleague Fritz Haubold for effective discussions in the field and the proofreading of the manuscript. Also thanks to Sieglinde Gerstenhauer and Beate Winkler for lab work. Special thanks to "Seilitzer Kaolin- und Tonwerk GmbH”, to "Zschaitzer Sandund Kiesgruben GmbH" and to "Ostrauer Kalkwerk GmbH" for giving always access to the studied sections. Mr. Dürasch from "Ostrauer Kalkwerk GmbH” supported all our activities in his pit and was always interested in our progress.

Finally, the authors want to thank all anonymous reviewers 
for the helpful comments. Special thanks to Manfred Frechen who gave us fruitful advices and was always interested in the improvement of this paper.

\section{References}

Adamiec, G. $\mho$ Aitken, M. (1998): Dose-rate conversion factors: update - Ancient TL, 16: 37-50.

Aitken, M. \& Xie, J. (1992): Optical dating: Recuperation after bleaching. - Quaternary Science Reviews, 11: 147-152.

Altermann, M., HaAse, G., Lieberoth, I. \& Ruske, R. (1978): Lithologie, Genese und Verbreitung der Löß- und Schuttsedimente im Vorland der skandinavischen Vereisungen. - Schriftenreihe der Geologischen Wissenschaften, 9: 231-255.

Antoine, P., Rousseau, D.D., Zöller, L., Lang, A., Munaut, A.V., Hatte, C. \& Fontugne, M. (2001): High-resolution record of the last Interglacial-glacial cycle in the Nussloch loess-palaeosol sequences, Upper Rhine Area, Germany. - Quaternary International, 76/77: 211-229.

Antoine, P., Rousseau, D.D., Moine, O., Kunesch, S., Hatté, C., Lang, A., Tissoux, H. \& Zöller, L. (2009): Rapid and cyclic aeolian deposition during the Last Glacial in European loess: a high-resolution record from Nussloch, Germany. - Quaternary Science Reviews, 28 (25-26): 1-19.

Bibus, E., Frechen, M., Kösel, M. \& RÄhle, W. (2007): Das jungpleistozäne Lößprofil von Nußloch (SW-Wand) im Aufschluss der Heidelberger Zement AG. - Eiszeitalter und Gegenwart, 56(4): 227-255.

BIERING, K. \& FrüHAUF, M. (1999): Untersuchung zu den natürlichen Schwermetallgehalten von Lößen im mitteldeutschen Raum. - Hallesches Jahrbuch für Geowissenschaften, Reihe A, 21: 83-96.

Dearing, J. (1999): Enviromental Magnetic Susceptibility. Using the Bar tington MS2 System. - Bartington Instruments, 2. ed., 54 S.; Oxford.

EISSMANN, L. (1964): Ausbildung und Gliederung des Pleistozäns in Mittelsachsen (Raum Döbeln-Riesa). - Geologie, 13: 942-969.

EIssmanN, L. (1994): Grundzüge der Quartärgeologie Mitteldeutschlands (Sachsen, Sachsen-Anhalt, Südbrandenburg, Thüringen). - In: L. Eissmann \& T. LitT (Hg.) Das Quartär Mitteldeutschlands - Ein Leitfaden und Exkursionsführer mit einer Übersicht über das Präquartär des Saale-Elbe-Gebietes, Altenburger Naturwissenschaftiche Forschungen, Bd. 7: 55-136, Mauritianum, Altenburg.

FINK, J. (1964): Die Subkommision für Lößstratigraphie der Internationalen Quartärvereinigung. - Eiszeitalter und Gegenwart, 15: 229-235.

Gallwitz, H. (1937): Fließerde und Frostspalten als Zeitmarken im Löß bei Dresden. - Geologische Rundschau, 28: 612-623.

GelLeRT, J.F. (Hg.) (1965): Die Weichselvereisung auf dem Territorium der Deutschen Demokratischen Republik. - 261 S.; Berlin (Akademie-Verlag).

GrahmanN, R. (1925): Diluvium und Pliozän in Nordwestsachsen: - Abhandlungen der Mathematisch-Physischen Klasse der Sächsischen Akademie der Wissenschaften, Bd. 39, 82 S.; Leipzig (Hirzel).

GrahmanN, R. (1932): Der Löss in Europa. - Mitteilungen der Gesellschaft für Erkunde 51: 5-24, Leipzig.

HaAse, G. (1963): Stand und Probleme der Lößforschung in Europa. - Geographische Berichte, 8(2): 97-129.

HaAse, G. (1968): Die Lössrandstufe in Nordsachsen. In: Periglazial-Löß Paläolithikum: - Exkursionsführer der VII. Hauptversammlung der Geographischen Gesellschaft der DDR, Leipzig.

HaAse, G., Lieberoth, I. \& Ruske, R. (1970): Sedimente und Paläoböden im Lößgebiet. - In: H. Richter, G. HAAse, I. Lieberoth \& R. Ruske (Hg.) Periglazial-Löß-Paläolithikum im Jungpleistozän der Deutschen Demokratischen Republik. - Ergänzungsheft zu Pertermanns Geographischen Mitteilungen, Bd. 274: 99-212, Quartärkomitee der DDR bei der Deutschen Akademie der Wissenschaften zu Berlin, Gotha, Leipzig.

Hamann, C. (2010): Quartäre Molluskenfunde im mittelsächsischen Lösshügelland. - Biostratigraphische Untersuchungen der Profile Zehren, Ostrau und Gleina. - Diplomarbeit, Technische Universität Dresden, Lehrstuhl der Physische Geographie, unpublished.

Koch, R. \& Neumeister, H. (2005): Zur Klassifikation von Lößsedimenten nach genetischen Kriterien. - Zeitschrift für Geomorphologie, 49(2): 183-203.

Lieberoth, I. (1959): Beobachtungen im nordsächsischen Lößgebiet. Zeitschrift für Pflanzenernährung Düngung Bodenkunde, 86 (131)(2): 141-155.

Lieberoth, I. (1962a): Die jungpleistozänen Lösse Sachsens im Vergleich zu denen anderer Gebiete. Ein Beitrag zur Würmchronologie. - Petermanns Geographischen Mitteilungen, 106(2): 188-198.
Lieberoth, I. (1962b): Die mittel- und jungpleistozänen Lösse Nordsachsens. - In: G. VIENT (Hg.) Das Pleistozän im sächsisch-thüringischen Raum - Exkursionsführer, 51-61, Geologische Gesellschaft in der Deutschen Demokratischen Republik, Leipzig.

Lieberoth, I. (1963): Lößsedimentation und Bodenbildung während des Pleistozäns in Sachsen. - Geologie, 12(2): 149-187.

Lieberoth, I. (1964a): Einige Bemerkungen zu paläopedologischen Problemen bei der Gliederung der Löße. - Berichte der Geologischen Gesellschaft der DDR, 9(Sonderheft 2): 689-695.

Lieberoth, I. (1964b): Bodenbildung aus Löß während des Pleistozäns und Holozäns in Sachsen. - Habilitation, 289 S.; Universität Leipzig.

Lieberoth, I. \& HAASe, G. (1964): Lößexkursion Nordsachsen. - In: G. HAAse \& R. Ruske (Hg.) 3. Arbeitstagung der Subkommission für Lößstratigraphie der INQUA-Exkursionsführer, 27-37, Leipzig.

LožEK, V. (1964): Quartärmollusken der Tschechoslowakei. Rozpravy Ústredního ústavu geologického, 31, 375 S.; Praha (Verlag der Tschechoslowakischen Akademie der Wissenschaften).

Meng, S. (2003): Kartierung des Quartärs und der Trias in der Umgebung von Freyburg/ U. - Diplomarbeit, Universität Halle, unveröffentlicht.

Neumeister, H. (1966): Die Bedeutung äolischer Sedimente und anderer Periglazialerscheinungen für die Bodenentwicklung in der Umgebung von Leipzig. - Dissertation, Math.-Nat. Reihe 15, 244 (+160) S.; Math.-Nat. Fak. Karl-Marx-Universität Leipzig.

Oexle, J. (Hg.) (2000): Sachsen: archäologisch - 12000 v. Chr. - 2000 n. Chr. Katalog zur Ausstellung „Die Sächsische Nacht“. - Landesamt für Archäologie mit Landesmuseum für Vorgeschichte Dresden, 88 S.; Dresden.

Pietzsch, K. (1922): Erläuterungen zur geologischen Spezialkarte von Sachsen. Blätter Wilsdruff und Tanneberg-Deutschenbora. Leipzig, 2. Aufl.

Richter, H., HaAse, G., Lieberoth, I. ¿ Ruske, R. (Hg.) (1970): Periglazial-Löß-Paläolithikum im Jungpleistozän der Deutschen Demokratischen Republik, Petermanns Geogrophischen Mitteilungen, Bd. Ergänzungsheft 274, 422 S.; Berlin (VEB Hermann Haack).

RICKEN, W. (1983): Mittel- und jungpleistozäne Lößdecken im südwestlichen Harzvorland. - In: H.R. Bork \& W. Ricken (Hg.) Bodenerosion, Holozäne und Pleistozäne Bodenentwicklung, Catena Supplement, 3: 95-138.

Ruske, R., Schulz, W. ¿ WüNsche, M. (1962): Pleistozäne Ablagerungen im Gebiet südlich von Leipzig und der unteren Unstrut unter besonderer Berücksichtigung der Lösse und fossilen Böden. - In: G. Vient (Hg.) Das Pleistozän im sächsisch-thüringischen Raum - Exkursionsführer, 99-112, Geologische Gesellschaft in der Deutschen Demokratischen Republik, Leipzig.

Ruske, R. \& Wünsche, M. (1964a): Lößexkursion Unteres Unstruttal. - In G. Haase \& R. Ruske (Hg.) 3. Arbeitstagung der Subkommission für Lößstratigraphie der INQUA-Exkursionsführer: 17-26, Leipzig.

Ruske, R. \& Wünsche, M. (1964b): Zur Gliederung des Pleistozäns im Raum der unteren Unstrut. - Geologie, 13: 211-222.

Schirmer, W. (2000): Eine Klimakurve des Oberpleistozäns aus dem rheinischen Löss. - Eiszeitalter und Gegenwart, 50: 25-49.

Schirmer, W. (2004): Terrestrischer Klimagang des MIS 3. - In: DEUQUA Meeting Abstract Volume, 74, DEUQUA, Amsterdam.

Schlichting, E., Blume, H.P. \& Stahr, K. (1995): Bodenkundliches Praktikum. Eine Einführung in pedologisches Arbeiten für Ökologen, insbesondere Land- und Forstwirte und für Geowissenschaftler. - Pareys Studientexte, Bd. 81. 2., neubearbeitete Aufl., 259 S.; Berlin (Blackwell Wissenschafts-Verlag).

Schönhals, E., Rohdenburg, H. \& Semmel, A. (1964): Ergebnisse neuerer Untersuchungen zur Würmlöß-Gliederung in Hessen. - Eiszeitalter und Gegenwart, 15: 199-206.

SEmmel, A. (1968): Studien über den Verlauf jungpleistozäner Formung in Hessen. - Frankfurter Geographische Hefte 45. Verlag Waldemar Kramer, Frankfurt am Main.

Semmel, A. (1997a): Referenzprofile des Würmlösses im Rhein-Main-Gebiet. - Jahresberichte der Wetterauischen Gesellschaft für die Gesamte Naturkunde zu Hanau, 148: 37-47.

Semmel, A. (1997b): Stop 3: Loess section of Mainz Weisenau. - In: Excursion Guide, Internat. Working Meeting Palaeopedology of ISSS and INQUA: 60-72.

Semmel, A. (1989): The importance of loess in the interpretation of geomorphological processes and for dating in the Federal Republic of Germany. - Catena Supplement, 15: 179-188.

Zöller, L., Rousseau, D.D., JäGer, K.D. ひ KuKla, G. (2004): Last interglacial, Lower and Middle Weichselian - a comparative study from the Upper Rhine and Thuringian loess areas. - Zeitschrift für Geomorphologie, 48(1): 1-24. 